\title{
Effect of Organic Residues on Pesticide Behavior in Soils: A Review of Laboratory Research
}

\author{
María J. Carpio (D), María J. Sánchez-Martín (D), M. Sonia Rodríguez-Cruz (D) and Jesús M. Marín-Benito *(D) \\ Institute of Natural Resources and Agrobiology of Salamanca (IRNASA-CSIC), 40-52 Cordel de Merinas, \\ 37008 Salamanca, Spain; mjose.carpio@irnasa.csic.es (M.J.C.); mjesus.sanchez@irnasa.csic.es (M.J.S.-M.); \\ msonia.rodriguez@irnasa.csic.es (M.S.R.-C.) \\ * Correspondence: jesusm.marin@irnasa.csic.es; Tel.: +34-923-219-606; Fax: +34-923-219-609
}

check for updates

Citation: Carpio, M.J.; Sánchez-Martín, M.J.; Rodríguez-Cruz, M.S.; Marín-Benito, J.M. Effect of Organic Residues on Pesticide Behavior in Soils: A Review of Laboratory Research. Environments 2021, 8, 32. https://doi.org/10.3390/ environments 8040032

Academic Editor:

Helvi Heinonen-Tanski

Received: 25 February 2021

Accepted: 11 April 2021

Published: 14 April 2021

Publisher's Note: MDPI stays neutral with regard to jurisdictional claims in published maps and institutional affiliations.

Copyright: (C) 2021 by the authors Licensee MDPI, Basel, Switzerland. This article is an open access article distributed under the terms and conditions of the Creative Commons Attribution (CC BY) license (https:// creativecommons.org/licenses/by/ $4.0 /)$.

\begin{abstract}
The management of large volumes of organic residues generated in different livestock, urban, agricultural and industrial activities is a topic of environmental and social interest. The high organic matter content of these residues means that their application as soil organic amendments in agriculture is considered one of the more sustainable options, as it could solve the problem of the accumulation of uncontrolled wastes while improving soil quality and avoiding its irreversible degradation. However, the behavior of pesticides applied to increase crop yields could be modified in the presence of these amendments in the soil. This review article addresses how the adsorptiondesorption, dissipation and leaching of pesticides in soils is affected by different organic residues usually applied as organic amendments. Based on the results reported from laboratory studies, the influence on these processes has been evaluated of multiple factors related to organic residues (e.g., origin, nature, composition, rates, and incubation time of the amended soils), pesticides (e.g., with different use, structure, characteristics, and application method), and soils with different physicochemical properties. Future perspectives on this topic are also included for highlighting the need to extend these laboratory studies to field and modelling scale to better assess and predict pesticide fate in amended soil scenarios.
\end{abstract}

Keywords: soil amendment; organic matter; dissolved organic carbon; agriculture; pesticide fate; dynamics; laboratory experiments

\section{Introduction}

The use of large quantities of pesticides in today's intensive agricultural systems is a widespread practice for controlling pests, diseases and weeds. This increases the yield per hectare, ensuring the food supply for the world's ever-growing population [1,2], which currently stands at over 7.7 billion people, and is estimated to rise above 9.6 billion by 2050, and reach nearly 11 billion around 2100 [3]. The application of a wide range of pesticides is considered a regular and required practice in agriculture, as almost $45 \%$ of annual food production is lost due to pest infestation or the competition between crops and weeds for soil nutrients [4]. In fact, 3.5 million tons of pesticides are being used, of which $47.5 \%$ are herbicides, $29.5 \%$ are insecticides, $17.5 \%$ are fungicides, and 5.5\% are other pesticides [5]. The global pesticide market recorded a value of nearly USD 84.5 billion in 2019 , increasing at an annual growth rate of $4.2 \%$ since 2015 , and it is likely to reach $11.5 \%$ with a value of nearly USD 130.7 billion by 2023 [6]. The ten countries consuming the most pesticide in the world are China, USA, Argentina, Thailand, Brazil, Italy, France, Canada, Japan, and India [7].

However, this extensive use of pesticides over recent decades is now of considerable environmental concern because of the release of mobile and/or persistent pollutants into the environment, and the potential accumulation of these toxic substances in soils and/or waters [8-10]. The fate of pesticides and their degradation products determines the contamination of the soil, water and air ecosystems over time. Moreover, if agrochemicals 
remain in the crops, they could finally enter the food chain, posing a threat to human, animal, and plant welfare [11-14].

The contamination of agricultural soils with pesticides could lead to changes in their chemical and biological properties, affecting their quality and causing a negative impact on crop yields [15]. They may impair soil microbial biodiversity and enzymatic activity (a vital indicator of soil tolerance to pollutants), and the associated degradation of soil organic matter (OM) [16,17]. Many reports are available on these negative effects on soil microbial communities [17,18], and on the processes associated with microbial activities [19].

A recent study involving 317 agricultural topsoil samples from the European Union and 76 pesticide residues as target compounds has revealed that $83 \%$ of the soils have been contaminated by one or more residues [9]. The contamination of surface and ground waters by pesticides has also been detected in recent years, probably due to deficient pesticide management, and increased by precipitation and/or irrigation that give rise to the runoff or leaching process of these compounds through the soil [20-23]. In fact, the contamination of water by pesticides is increasing in agricultural areas across different countries, and a broad range of pesticide concentrations has been found, in some cases exceeding the limit established for drinking water by European Union (EU) legislation $\left(0.1 \mu \mathrm{g} \cdot \mathrm{L}^{-1}\right)$ [24-26].

These environmental contamination data highlight the need to roll out strategies to optimize agricultural sustainability by maximizing crop productivity and reducing or preventing soil and water contamination by pesticides. This has been widely addressed in recent years due to the requirement to meet European Community regulations [27]. One of these strategies is based on the in-situ application of organic residues as organic amendments [28]. This method is a common agricultural practice which allows increasing soil OM content, and it can be used to control soil and water contamination by pesticides: (i) promoting the immobilization of pesticides in soil OM, enhancing their subsequent biodegradation, and preventing or reducing their potential mobility into water resources [28-30], and (ii) delivering nutrients to the soil by increasing $\mathrm{OM}$ content to promote soil fertility and plant growth and stimulate ecological restoration with concomitant benefits for the health of the soil ecosystem [11]. In addition, organic materials require minimal pre-treatment before their application to the soil because of their biological origin [31].

Large amounts of organic residues are generated from livestock, urban, agricultural and industrial activities, and their management is a topic of environmental and social interest in many countries today due to the problems surrounding their disposal $[32,33]$. In general, these wastes have a high OM content, and they could be used as organic amendments in agriculture, with this being one of the most sustainable options and with greater environmental advantages. Moreover, numerous organic residues could perform as possible sorbents for pesticides [34-36]. These studies have assessed the effects that organic carbon (OC) from exogenous sources have on the behavior and environmental fate of pesticides in soils due to the affinity of pesticides, which are generally hydrophobic substances, by these organic materials. The OC of the amendments, depending on their nature, composition and content, can modify the main physicochemical processes of pesticides (adsorption-desorption, dissipation and leaching) in soils. These processes determine their efficiency as well as the dissipation or persistence of these compounds in the soil and their effects as potential environmental contaminants of the soil and surface or ground waters [37].

The aim of this review article is to analyze the influence that organic residues applied as soil organic amendments have on the environmental fate of pesticides. It has focused mainly, albeit not exclusively, on research papers published in the last ten years. Special interest has been directed toward the factors that affect the adsorption-desorption, dissipation, and leaching of pesticides in amended soils at laboratory scale. Future perspectives on the joint application of pesticides and organic amendments are also included. 


\section{Organic Residues as Soil Amendments}

\subsection{Origin, Characteristics and Impact on Soil Properties}

The use of organic residues as soil amendments to improve soil quality and fertility dates back thousands of years. Animal manure and human sewage was already being applied to the soil by Greeks and Romans [38]. Waste products such as crop residues, seashells, farmyard manure and others were previously used to enhance crop growth [39]. The use of organic residues as soil organic amendments is still a widespread and common practice in modern agriculture. In fact, this agronomic practice is on the rise in Europe, the US, and many other countries. Its application improves soil properties, maintaining soil health and productivity, while reducing the disposal of organic wastes into landfills, with the consequent environmental benefits [40]. The restoration and maintenance of soil OM content is one of the main benefits of the application of organic residues to agricultural soil because they add exogenous $\mathrm{OM}$, which contributes greatly to soil fertility and longterm use [41]. OM is the main soil property, as it supports and interrelates the biological, chemical and physical dimensions of soil fertility and health [42]. Furthermore, because $\mathrm{OM}$ also contributes to the process of sequestering carbon dioxide from the atmosphere (soil $\mathrm{C}$ uptake, and thus climate change mitigation), its improvement has been championed at international forums on food security and climate change [43].

Regarding the benefits that organic amendments have for soil biological properties, they directly stimulate microbial growth and biomass by providing energy and essential nutrients (especially N, P, K, Ca and Mg), or indirectly by promoting plant growth, and consequently the amount of root exudates in the rhizosphere [44]. Moreover, the presence of diverse substrates susceptible to enzymatic hydrolysis within the amendments stimulates soil microbial activities [45]. Soil microbial diversity and composition could also be affected due to a higher availability of nutrients and growth substrates present in the amendments, which increase the number of ecological niches and promote a variety of ecological interactions, such as competition and/or antagonism between organisms [46]. The beneficial effects of organic amendments on the biomass, activity, and diversity of soil organisms have a long-term beneficial impact on soil health $[47,48]$ and also contribute to different ecosystem services ( $\mathrm{C}$ and nutrient cycling, disease suppression, etc.). However, it is important to stress that microbial responses to the application of organic amendments vary greatly depending on the nature and lability of the amendments' OM [49].

Organic amendments also influence soil chemical properties in a positive way. Indeed, their favorable effects on soil microbial communities are often linked to changes in soil chemical characteristics [50,51]. Several organic amendments may have a direct effect on soil fertility by providing a wide variety of macro- and micro-nutrients, which support plant and microbial growth [52]. In addition, they may affect soil $\mathrm{pH}$ and enhance the cation exchange capacity, thus indirectly influencing nutrient availability, microbial activity and, therefore, soil fertility [53]. Nutrient availability may be influenced by the amendment's biochemical composition, and in particular by its carbon-nitrogen $(\mathrm{C} / \mathrm{N})$ ratio, which may limit soil microbial growth and activity, thereby influencing the rate of OM decomposition and the patterns of nutrient release [49,54].

Soil physical characteristics can also be positively influenced by the application of organic amendments. Accordingly, the addition of exogenous OM directly improves soil structure (better porosity, aggregation and structural stability) [55] and water retention capacity [56], with the associated positive effects previously noted for soil performance and crop productivity. In turn, the stimulation of soil microbial communities through the use of organic amendments may also indirectly improve soil structure, as microbial activity (e.g., through the secretion of exopolysaccharides) and particularly hyphal growth significantly influence soil aggregation and aggregate stability [57]. The increase in soil porosity often reduces soil crusting and bulk density, thus favoring the movement of air and water through the soil matrix, the exploratory capacity of plant root systems, and the development of a suitable environment for soil biological communities [58]. Moreover, organic amendments influence particle size distribution, connectivity and the total surface 
area within the soil, increasing the number and types of available niches for biological colonization [49].

The potential positive effects of organic amendments on the soil ecosystem depend on many factors, such as their origin (forestry, farming, urban or industrial wastes, etc.), material stage (solid, semisolid, liquid), subjected or not to treatments (composting, anaerobic digestion, etc.), composition, stability, maturity, and application frequency, method and rate. Moreover, soil type, cropping system, and weather conditions are also important factors. In order to identify the different properties, agronomic potential, and limitations of any given organic amendment for soil and crop health, a thorough characterization of both the organic amendment and the agroecosystem itself needs to be performed before its application [49]. In this sense, however, it is also important to stress that the use of organic residues as a soil organic amendment is not devoid of risk. This agricultural practice may sometimes have unwanted effects on the environment depending on the factors previously cited (nature, origin, dose of application, etc.). Some of the potential negative effects analyzed and determined in the literature are the increase in soil electrical conductivity and its salinization, negative impacts on the sensitivity and resilience of soil bacteria communities, and the release of pollutants into the soil and/or waters (nitrate, heavy metals, antibiotics, polycyclic aromatic hydrocarbons, dioxins, PCBs, etc.) [51,59-63].

\subsection{European Legislation on the Use of Organic Residues as Soil Amendments}

Economic growth in the EU continues to increase the volume of residues generated. As a result, waste disposal has become a social and environmental concern because it causes the unnecessary loss of materials and energy, environmental damage, and negative effects on health and quality of life. Landfills, for example, occupy space and can pollute air, water and soil, while incineration leads to emissions of air pollutants. The long-term goal of $\mathrm{EU}$ waste management policies is to decrease the amount of residues generated, and when their generation is unavoidable, promote them as a resource and achieve higher levels of recycling and safe waste disposal, reducing the negative impacts on the environment and health and ushering in an efficient "Recycling Society" [64].

Two common EU targets for 2030 are recycling $65 \%$ of municipal solid waste (MSW) and reducing the corresponding landfill to a maximum of $10 \%$ of this figure [65]. In 2018, 5.2 tons of residues were generated per EU inhabitant, and 38.7\% of waste in the EU was landfilled and 38.1\% was recycled [64]. According to the European Compost Network [66], between around 118 and 138 million tons of bio-residues are generated annually across the $\mathrm{EU}$, of which only about $40 \%$ (equivalent to 47.5 million tons/year) is efficiently recycled into high quality compost and digestate. Based on the Status 2019 report [66], a total of 47.5 million tons of bio-residues are treated in 4274 plants, and the predominant treatment process is composting.

Considering that up to $50 \%$ of MSW is organic, the bio-residue fraction has a significant role in recycling and developing the circular economy. Most of the MSW generated in the EU is still landfilled $(24 \%)$ or incinerated $(27 \%)$, and less than half is recycled $(31 \%)$ or composted (17\%) [64]. According to the data available, there has not been any increase in bio-residue recycling in recent years [67]. Moreover, waste management practices vary widely across EU member countries, with many continuing to send large amounts of MSWs to landfills.

Soil health and quality have been seriously compromised in recent years by constant changes in land use and the depletion of soil OM [68]. Indeed, approximately $45 \%$ of Europe's topsoil $(0-30 \mathrm{~cm})$ has a low OM $(<3.5 \%)$ content [69,70], and the soils in Mediterranean regions are highly susceptible to its loss, with almost $75 \%$ recording a low $(\leq 2 \%)$ or very low $(\leq 1 \%)$ OM content [71], whereby most of them are considered degraded. The reuse of organic residues as soil amendments in agriculture is an ancient but increasingly popular practice that not only helps to reduce the dependency on agrochemicals, but also constitutes an ecologically, economically, and socially acceptable alternative to landfill 
disposal and incineration, contributing at the same time to the objectives of the EU policies of "Zero Waste", "End-Of-Waste", and the "Circular Economy Strategy" [46,72].

It should nonetheless be stressed that an organic residue must meet a series of requirements for its potential use as a soil amendment. According to Commission Decision (EU) 2015/2099 of 18 November 2015 establishing the ecological criteria for the award of the EU Ecolabel for growing media, soil improvers and mulch [65], the following definitions apply: "1. Soil amendment means a fertilizer product incorporated into the soil in situ whose function is to maintain, improve or protect the physical or chemical properties, structure or biological activity of the soil, with the exception of limestone amendments, and 2. Organic soil amendment means a soil amendment that contains carbonaceous materials whose main function is to increase the OM content of the soil". Among the organic residues potentially applicable to soil are those from the following activities: urban (sewage sludge (SS) or MSW), agricultural (crop residues), livestock (manure and slurry), and agro-industrial (wine, beer, sugar and olive production, and mushroom cultivation) [38].

The addition of $\mathrm{OM}$ through organic amendments plays a major role in the fate of xenobiotic compounds including pesticides [73,74]. The solid organic matter (SOM) and dissolved organic matter (DOM) of these amendments applied to the soil may modify the physicochemical behavior of pesticides (e.g., adsorption-desorption, persistence, bioavailability, degradation, and mobility), affecting soil quality and surface and ground waters [34,75-79] (Figure 1).

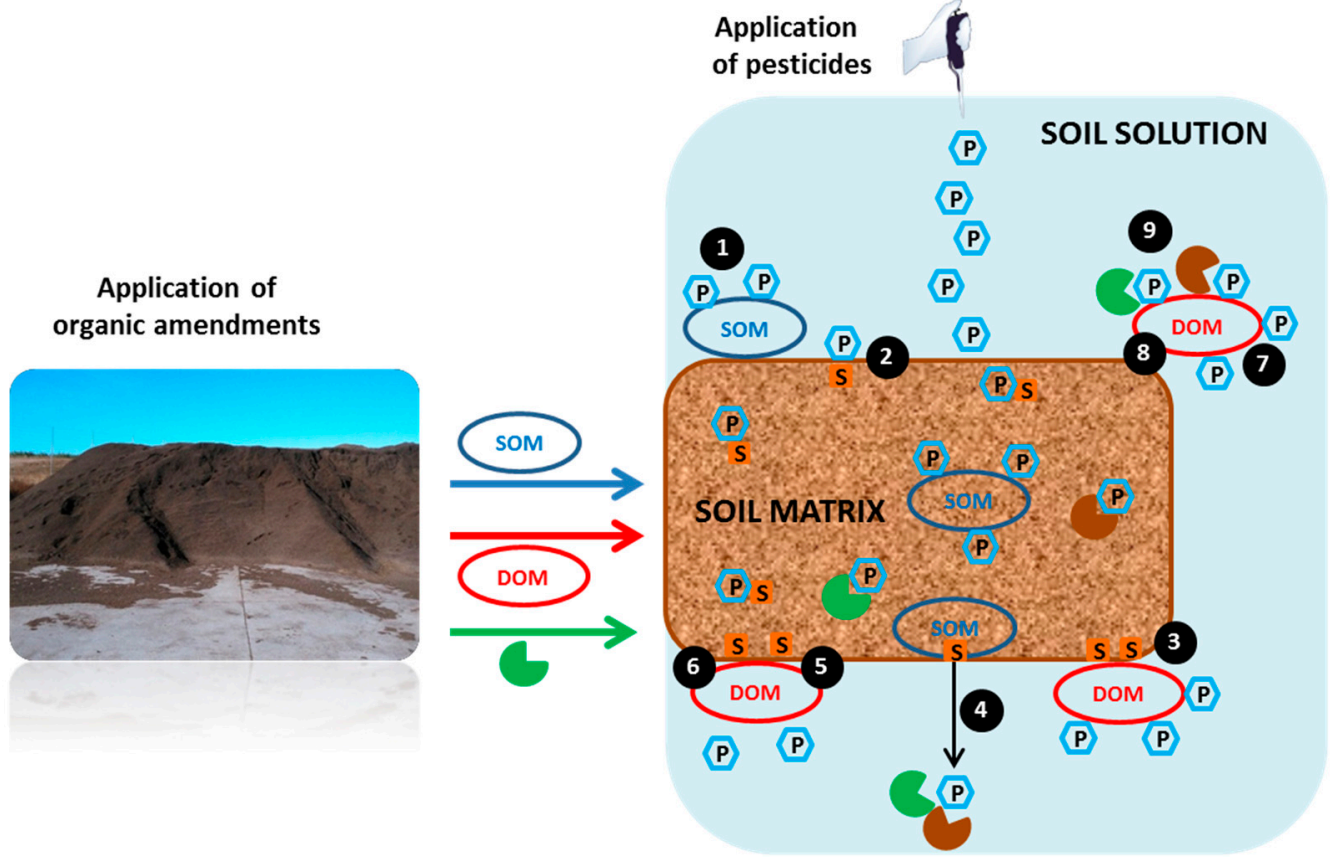

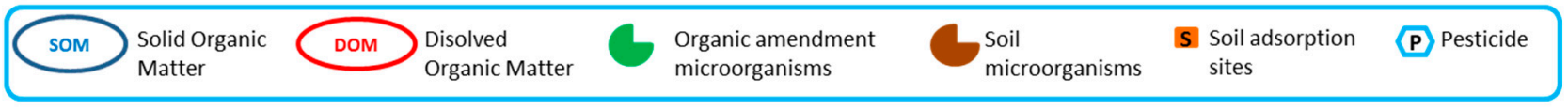

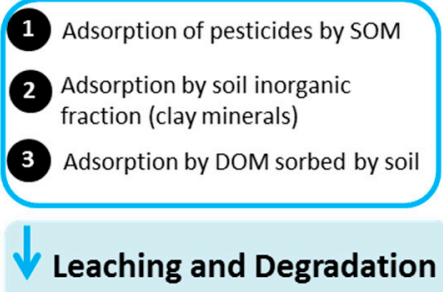

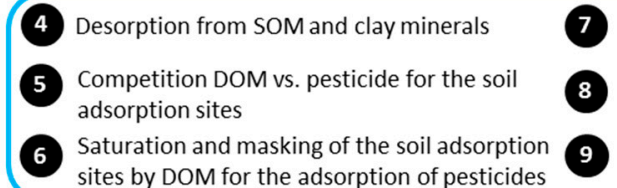

7 Co-sorption of pesticides by DOM or formation of mobile DOM-pesticides complexes

DOM with surfactants properties decreases the surface tension and increases pesticide solubility Biodegradation of pesticides in solution sites by DOM for the adsorption of pesticides

\section{Adsorption}

\section{Leaching, Bioavailability and Degradation}

Figure 1. Summary of the organic amendments' (solid organic matter (SOM) and dissolved organic matter (DOM)) effects on the processes controlling the fate of pesticides in soil. 


\section{Effect of Organic Residues on the Fate of Pesticides in Soil}

\subsection{Effect of Organic Residues on the Adsorption-Desorption of Pesticides}

The combined application of pesticides and organic residues in soils modifies the former's physicochemical behavior, mainly through their adsorption-desorption by the amended soils [78,79]. Organic amendments increase soil OC content, and this parameter is the most relevant factor influencing the adsorption process and the affinity of hydrophobic pesticides by soils $[80,81]$. Adsorption-desorption determines the environmental fate of any organic pollutants in the soil-water environment [82]; it directly or indirectly controls the availability of pesticides to be transported to surface waters by runoff or to groundwaters by leaching, to the air by volatilization, to be degraded/transformed by microbial attack, or be taken up by plants [83]. Thus, the weak adsorption and/or strong desorption of pesticides promotes leaching, run-off, volatilization, biodegradation and even ecotoxicological impacts on non-target organisms, including human beings, while strong adsorption prevents losses of pesticides by such processes [84].

Accordingly, the addition of organic amendments to soil could lead to a greater or lesser degree of pesticide immobilization in the amended soil. This effect has consequences for pesticide degradation, persistence or mobility, enhancing a pesticide's subsequent chemical, physical, and biological transformation or degradation, decreasing its transport through the soil profile, and consequently reducing groundwater pollution in some cases $[28,78]$. However, it could also affect the final concentration bioavailable for absorption by the targeted weeds [37]. Therefore, adsorption and desorption processes help to understand how to predict the mobility and availability of pesticides in unamended and amended soils. Numerous references report the ability that organic amendments have to adsorb pesticides [29,85-87].

Adsorption is a physicochemical process in which pesticide molecules are retained on a solid surface (especially by the soil colloidal fraction) within a solution through hydrophobic interactions, van der Waals forces, $\pi-\pi$ interaction, and covalent, ionic or hydrogen bonds [88,89]. Soil OM and its more active components, humic acids (HAs) and fulvic acid (FAs), are the principal adsorbents for pesticides, followed by clay colloids and oxyhydroxides of iron and manganese, which interact with pollutants when they reach the soil $[90,91]$. HA is the OM fraction with the highest reactivity (determined by the number and type of functional groups) and largest surface area. OM's highly variable composition means it can interact with neutral or ionizable molecules [75]. The pesticide adsorption capacity varies, in general, according to the physicochemical characteristics of the adsorbent and pesticide properties, mainly its water solubility and its hydrophobic, polar, or ionic character [37,92].

The nature and composition of the amendment's OM vary, with the consequent difficulty in predicting its efficiency for adsorbing pesticides [34,76]. The addition of organic amendments to soil introduces not just SOM but also DOM (Figure 1). The influence of the SOM and DOM content of organic residues on the adsorption of pesticides with different characteristics by amended soils has been frequently studied $[34,76,77]$. The DOM content in unamended soil is usually very low, but it could become relevant if the organic amendment has a high content in this fraction [93]. DOM is a diverse mixture of complex compounds with different chemical structures and molecular weights that might enhance the formation of multiple interactions with organic pesticides, controlling their distribution in the soil [94]. This is why DOM may modify the movement of pesticides, generally decreasing their adsorption by SOM and increasing their leaching, leading to groundwater contamination $[78,95,96]$, although other authors have indicated that DOM could also be adsorbed by the soil, increasing the adsorption of pesticides and decreasing their leaching [97].

Different processes have been proposed to explain the decreased adsorption of pesticides in the presence of DOM [94,98-100] (Figure 1). These include the competition between DOM and pesticide molecules for the adsorption sites in soil, the saturation of soil adsorption sites by DOM, masking these sites for the adsorption of pesticides, the 
co-sorption of pesticides by DOM, and the formation of mobile DOM-pesticides complexes. Some authors have also indicated that DOM has characteristics similar to surfactants with the capacity to decrease surface tension and increase the solubility of pesticides, reducing their adsorption [101]. The extent and nature of DOM-pesticide interactions depend on factors such as pesticide molecular weight and polarity [102]. These relative effects of DOM will be greater for more hydrophobic chemicals, and will be influenced by the concentration, source, size, polarity, and molecular configuration of the organic colloids [95].

Table 1 includes a summary of the main results obtained from the recent literature on the adsorption and/or desorption of pesticides by some organic residues and by soils amended with different organic residues used as amendments. An organic material widely studied for these purposes is biochar (BC). It is an efficient adsorbent and a potential material for soil amendment [30]. It is a carbonaceous and porous product generated from the partial combustion of biomass, and its effects as soil amendment in the adsorptiondesorption of pesticides has been assessed from different points of view. The effects of different types of $B C$, treatments or aging periods, and their different doses or application forms as organic amendments in soils have been reported for pesticides with different characteristics. Parlavecchiaetal. [103] have investigated the effect of two types of BC from grape vine pruning residues (BC-G) and spruce wood (BC-S) and two vermicomposts (VC) involving digestates from a mixture of manure and olive mill wastewater (VC-M) and buffalo manure (VC-B) in the sorption-desorption capacity of the fungicide metalaxyl-M. Both types of amendments ( $\mathrm{BC}$ and $\mathrm{VC}$ ) have a significant capacity to adsorb the highwater-soluble fungicide. However, $\mathrm{BC}$ has recorded a much higher sorption efficiency than VC and lower desorption, which is explained by the composition and structural differences in OM between the two (VC has less aromatic carbon and a higher content of hydrophilic functional groups interacting with polar compounds and solvents than BC). Metalaxyl-M is adsorbed to a similar extent on the two VCs, while a different sorption behavior is observed in BC-G and BC-S due to their different porous structures. Likewise, Wu et al. [89] have assessed the effects of different types of $B C$ from peanuts $(B C P)$, chestnuts $(B C C)$, bamboo $(\mathrm{BCB})$, maize straw $(\mathrm{BCM})$, and rice husk (BCR), and the effects of $B C R$ aging on the sorption, degradation and bioavailability of the herbicide oxyfluorfen in various amended soils. The sorption capacity of the five BC differs significantly due to their physicochemical properties. The sorption capacity of BC for oxyfluorfen is significantly correlated with the specific surface area and elemental composition, but it decreases with longer aging time. $\mathrm{BC}$ reduces the bioavailability of oxyfluorfen in amended soils, but a higher bioavailability is recorded with an increase in the aging period of BC. Nevertheless, the sorption capacity of amended soil for oxyfluorfen after six months is still better than the unamended soil, highlighting that BCR is an effective way of reducing the risk of contaminating soil with oxyfluorfen, although it could also diminish the herbicide's bioavailability and efficacy. Deng et al. [104] have studies the effect that BC obtained from cassava residues at $750{ }^{\circ} \mathrm{C}$ $\left(\mathrm{MS}_{750}\right)$ applied at different rates between $0 \%$ and $5 \%$ has on the sorption-desorption and mobility of atrazine. The $\mathrm{MS}_{750}$ application significantly enhances the sorption capacity and decreases the sorption reversibility of atrazine in the amended soil compared to the unamended soil, due to the larger surface area and greater aromaticity of $\mathrm{MS}_{750}$ (with favorable sorption domains for organic compounds). Moreover, sorption affinity increases with higher $\mathrm{BC}$ application rates, although it is also influenced by solution $\mathrm{pH}$, ambient temperature, and contact time between soil and BC (equilibrium time). The entrapment of atrazine in micropore or pore deformation could lead to desorption hysteresis in BCamended soils.

Mendes et al. [105] have recently studied the effect that BC from cow bone applied to the topsoil or incorporated into the surface layer has on the sorption-desorption of the herbicides hexazinone, metribuzin, and quinclorac in an unamended soil, pure BC, and $\mathrm{BC}$-amended soil under laboratory conditions. The results indicate low values of $\mathrm{K}_{\mathrm{f}}$ adsorption and desorption constants in the unamended soil. $\mathrm{BC}$ increases these $\mathrm{K}_{\mathrm{f}}$ values, stimulating the retention of all the herbicides in the surface soil. The low $C$ content of $B C$ 
has a minimal impact on the total OC of amended soils, with the main changes occurring in pore size (up to $60,000 \mathrm{~nm}$ ), volume $\left(0.225 \mathrm{~cm}^{3} \mathrm{~g}^{-1}\right)$, and area $\left(133 \mathrm{~m}^{2} \mathrm{~g}^{-1}\right)$ to increase herbicide adsorption by the soil. The desorption data for all herbicides were consistent with the values found for adsorption in the unamended soil, where quinclorac was the herbicide with the highest $\mathrm{K}_{\text {foc }}$ (adsorption) and lowest $\mathrm{K}_{\text {foc }}$ (desorption). The desorbed amount of herbicides was close to zero after the addition of $\mathrm{BC}$ in the soil or in pure $\mathrm{BC}$, confirming the high adsorption potential of $\mathrm{BC}$ regardless of the material's method of application. Similar high sorption has been reported for two weak acid herbicides, aminocyclopyrachlor and mesotrione, in amended soils with the same cow bone char [106]. The comparison of organic residue application at varying rates and with two different particle size groups $(0.3-0.6$ and $0.15-0.3 \mathrm{~mm}$ ) indicates that higher $\mathrm{BC}$ application rates increases the adsorption and decreases the desorption of both herbicides, regardless of particle size.

The effectivity and rate of application of other organic residues as adsorbents of pesticides has also been reported in different studies. Marín-Benito et al. [107] have studied the effect of large amounts of lignocellulosic residues from forestry and industrial activities on the adsorption-desorption of certain pesticides by soils. The study involves two wood wastes (pine and oak wood) at two different doses ( $5 \%$ and $50 \%$ ) and various incubation times ( 0,5 and 12 months) in two soils with different textures (sandy loam and sandy clay). The effect on the adsorption-desorption of two herbicides and one fungicide (linuron, alachlor, and metalaxyl) has revealed that the application of oak or pine wood to soils increases the adsorption of linuron and metalaxyl by both soils, and of alachlor by the sandy loam soil at a lower dose $(5 \%)$, while the adsorption of the three pesticides increases under all conditions at the highest dose (50\%). The results also indicate the influence of soil type on alachlor desorption and/or its possible bioavailability from wood-soils, but not for linuron and metalaxyl, although this behavior changes with incubation time. The role of the nature of the OC ( $\mathrm{K}_{\mathrm{oc}}$ values) for sorption has been evidenced for alachlor and metalaxyl, but not for linuron. Other residues, such as the SS applied to the soil at various rates $\left(0.1 \%, 1 \%\right.$, and $\left.10 \% \mathrm{~W} \cdot \mathrm{w}^{-1}\right)$, have a non-significant effect on the sorptiondesorption of aminocyclopyrachlor and mesotrione [108]. Both herbicides follow a similar adsorption behavior in all treatments, although $\mathrm{K}_{\mathrm{d}}$ for mesotrione is $\approx 3.5$-fold higher than for aminocyclopyrachlor due to the latter's higher water solubility. This leads to a higher bioavailability of aminocyclopyrachlor in soil solution for its absorption by weeds and crops.

Fewer studies have addressed the adsorption-desorption of several pesticide-organic residue combinations or the amendment effect on soil physical properties. Duhan et al. [109] have studied the behavior of five herbicides commonly used in sugarcane production (imazapic, atrazine, hexazinone, diuron, and metribuzin) by eleven waste materials (mill muds) and by three soils amended with them at different rates (5-25\%, dry weight basis). The authors have observed that all the amendments enhance the adsorption efficiency for four of the five herbicides, depending on the rate of application, especially in the soil with low OC. Even at the lowest application rate, the adsorption of the herbicides increases from two to ten times. Mill muds in soil also reduce the rate and extent of herbicide desorption, especially at a 5\% application rate and for mobile herbicides such as metribuzin and atrazine. Marsico et al. [110] have studied the effect that the mucilage extracted from Chia seeds (Salvia hispanica L.) has as a soil amendment on soil physical properties and on the sorption-desorption behavior of four herbicides (MCPA, diuron, clomazone, and terbuthylazine) used in cereal crops. The assessment of the changes in the microstructural characteristics caused by the reactions between the mucilage and soil particles in three soils indicates that mucilage amendment reduces soil porosity due to a decrease in larger pores (radius $>10 \mu \mathrm{m}$ ) and a significant increase in finer pores (radius $<10 \mu \mathrm{m}$ ), as well as in particle surface. Higher herbicide adsorption has been observed in the amended soils than in the unamended ones. Moreover, herbicide desorption is severely inhibited in the amended soils. 
Although many organic amendments have proven to be effective adsorbents of pesticides, only a few studies have evaluated the functional groups involved in the adsorption process [111-114]. Accordingly, Gaonkar et al. [112] have used spectroscopy to characterize the DOM from two organic amendments (mixed waste compost and dried goat manure) and the amended soils, and assess their influence on the sorption of the insecticides dichlorvos and chlorpyrifos. The DOM contained large amounts of highly humified and aromatic molecules. DOM led to a non-significant increase in dichlorvos adsorption (hydrophilic pesticide), due mainly to the additional sites provided by the adsorbing DOM and no interactions between DOM and the insecticide in solution. However, a significant reduction in chlorpyrifos adsorption (hydrophobic pesticide) was observed, probably due to interactions between DOM and the insecticide mostly in solution, and to some extent at the soil/solution interface, increasing the solubilization of chlorpyrifos. This reduction in adsorption depended on the nature and concentration of the DOM, as well as on insecticide properties. In agreement with the adsorption results, chlorpyrifos desorption was significantly increased by the DOM residue. In another recent study, García-Delgado et al. [114] have determined the $\mathrm{OC}$ functional groups from four organic amendments (spent mushroom substrate (SMS), GC, manure, and SS) by elemental analysis and ${ }^{13} \mathrm{C}-\mathrm{NMR}$, and their effects on the adsorption of four herbicides with different structures (triasulfuron, chlorotoluron, flufenacet, and prosulfocarb) by two unamended and amended soils with different textures. The chemical composition and structure of the organic amendments (especially OC content and structural C type), and external factors such as herbicide polarity (hydrophobicity) and soil properties controlled the adsorption process. The adsorption of herbicides was promoted by carbon-rich organic amendments with aliphatic and aromatic structures, while the irreversible adsorption (hysteresis) of herbicides in the amended soils was enhanced by the abundance of O-alkyl and $\mathrm{N}$-alkyl groups of organic amendments.

\subsection{Effect of Organic Residues on Pesticide Leaching}

Pesticides run off from agricultural soils to surface waters when water exceeds the soil's infiltration capacity and move to groundwater by leaching or vertical movement in the soil profile. Large macropores act as preferential flow pathways in leaching, prompting the rapid movement of the pollutants through the unsaturated zone [115]. Pesticide runoff and leaching are the main sources of surface and ground water contamination by pesticides, causing environmental problems [116]. The physicochemical properties of the pesticides and soil properties (texture, clay content, $\mathrm{OM}$, and permeability) play a critical role in the leaching process [117].

Pesticides' leaching potential is generally favored by their high water solubility, long persistence, and low adsorption in soil [118]. Pesticides with an intermediate adsorption rate have a greater tendency to undergo losses through runoff, as weakly adsorbed compounds are more available for leaching through the soil from the surface, while strongly adsorbed ones are less so. Hence, minor leaching is expected in soils with a high OM content because of their greater adsorption [119]. The application of organic amendments to soils increases the soil OM content, but it may also increase the amount of DOM in the aqueous phase and, in general, enhance leaching, as previously explained in Section 3.1 [93] (Figure 1). Nevertheless, the greater or lesser leaching of pesticides in amended soils may not be due solely to the presence of additional SOM or DOM in amended soil, but also to structural changes in soil porosity induced by the higher soil OC content [37]. 
Table 1. Adsorption-Desorption of pesticides by organic residues and amended soils.

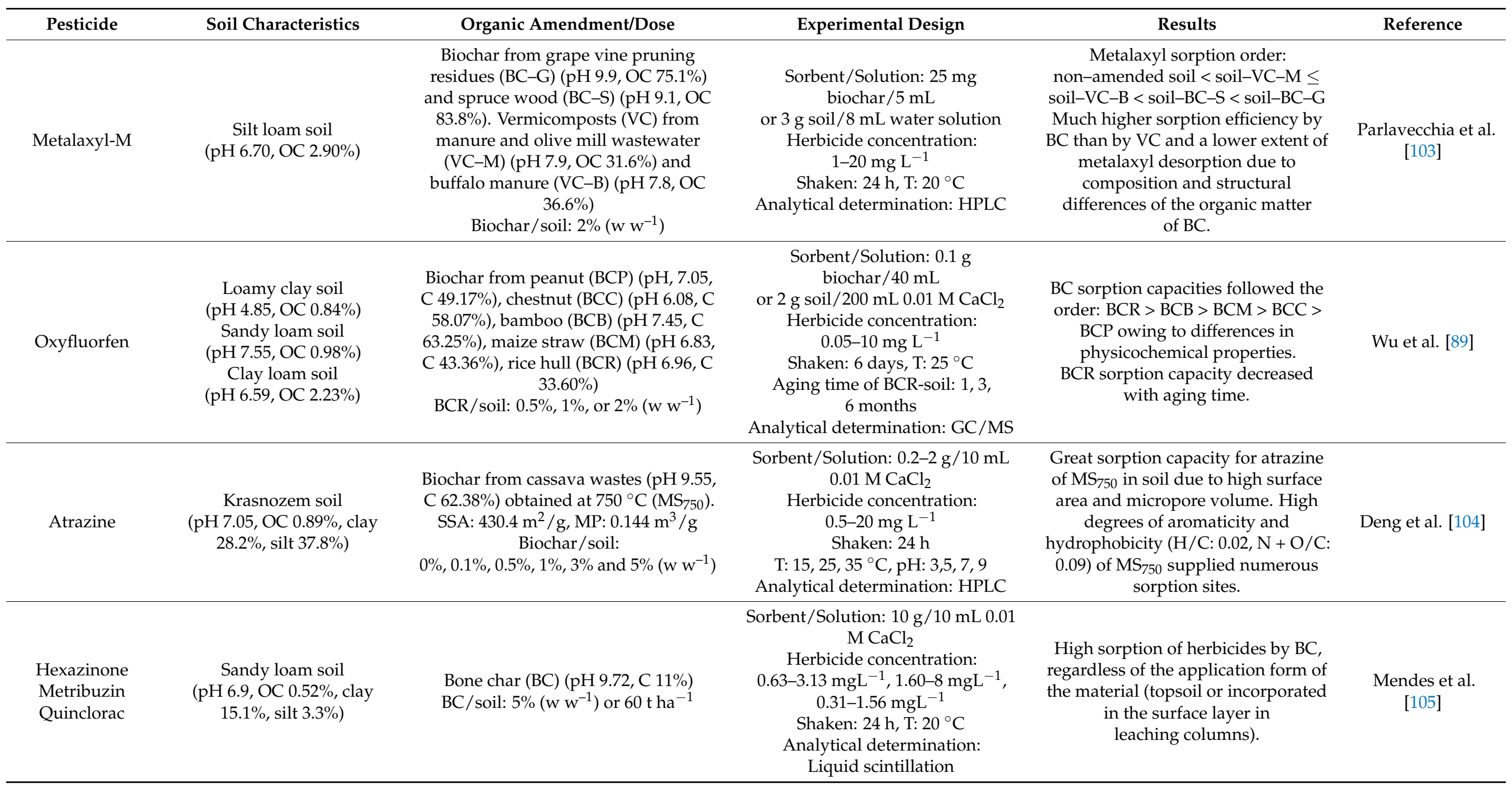


Table 1. Cont.

\begin{tabular}{|c|c|c|c|c|c|}
\hline Pesticide & Soil Characteristics & Organic Amendment/Dose & Experimental Design & Results & Reference \\
\hline $\begin{array}{l}\text { Aminocyclopyrachlor } \\
\text { Mesotrione }\end{array}$ & $\begin{array}{c}\text { Clay soil } \\
\text { or }(\mathrm{pH} 6.44, \text { OC } 2.73 \%) \text {, clay } \\
50.9 \% \text {, silt } 19.6 \%)\end{array}$ & $\begin{array}{c}\text { Bone Char (BC) }(\mathrm{pH} 9.72, \mathrm{C} 11 \%) \\
\mathrm{BC} / \mathrm{soil}: 0 \%, 1 \%, 5 \%, 10 \% \text {, and } 100 \% \\
\left(\mathrm{w} \mathrm{w}^{-1}\right) \text { or } 0,12,60,120 \text {, and } \\
1200 \mathrm{t} \mathrm{ha}^{-1} \\
\text { BC particle size groups: } 0.3-0.6 \text { and } \\
0.15-0.3 \mathrm{~mm}\end{array}$ & $\begin{array}{c}\text { Sorbent/Solution: } 10 \mathrm{~g} / 10 \mathrm{~mL} \\
0.01 \mathrm{M} \mathrm{CaCl}_{2} \\
\text { Herbicide concentration: } \\
0.051 \mathrm{mg} \mathrm{L}^{-1}\left(0.32 \mathrm{~Bq} \mathrm{~L}^{-1}\right) \\
\text { aminocyclopyrachlor } \\
5.0 \mathrm{mg} \mathrm{L}^{-1}\left(1.13 \mathrm{~Bq} \mathrm{~L}^{-1}\right) \text { mesotrione } \\
\text { Shaken: } 24 \mathrm{~h}, \mathrm{~T}: 20^{\circ} \mathrm{C} \\
\text { Analytical determination: } \\
\text { Liquid scintillation }\end{array}$ & $\begin{array}{l}\text { Higher BC rates (regardless of the } \\
\text { particle size) increased both } \\
\text { herbicides adsorption and decreased } \\
\text { their desorption. }\end{array}$ & $\begin{array}{l}\text { Mendes et al. } \\
\text { [106] }\end{array}$ \\
\hline $\begin{array}{l}\text { Linuron } \\
\text { Alachlor } \\
\text { Metalaxyl }\end{array}$ & $\begin{array}{c}\text { Sandy loam soil } \\
\text { (pH 6.3, OC } 0.51 \% \text {, clay } 11.8, \\
\text { silt } 13.6 \% \text { ), } \\
\text { Sandy clay soil (pH } 6.9, \text { OC } \\
1.04 \% \text {, clay } 38.1 \% \text {, silt } 5.8 \% \text { ) }\end{array}$ & $\begin{array}{c}\text { Pine Wood (OC } 41.6 \% \text {, DOM } 1.62 \% \text {, } \\
\text { lignin } 24.4 \% \text { ), oak wood (OC 38.5\%, } \\
\text { DOM 6.86\%, lignin } 18.2 \%) \\
\text { Wood/soil: } 5 \% \text { and } 50 \%\left(\mathrm{w} \mathrm{w}^{-1}\right)(40 \\
\left.\text { and } 400 \mathrm{t} \mathrm{C} \mathrm{ha}^{-1}\right)\end{array}$ & $\begin{array}{l}\text { Sorbent/Solution: } 5 \mathrm{~g} / 10 \mathrm{~mL} \text { water } \\
\text { solution } \\
\text { Herbicide concentration: } \\
1-25 \mathrm{mg} \mathrm{L}^{-1}\left(100 \mathrm{kBq} \mathrm{L}^{-1}\right) \\
\text { Shaken: } 24 \mathrm{~h}, \mathrm{~T}: 20^{\circ} \mathrm{C} \\
\text { Incubation times: } 0,5 \text { and } 12 \mathrm{months} \\
\text { Analytical determination: } \\
\text { Liquid scintillation }\end{array}$ & $\begin{array}{l}\text { Pesticide adsorption increased with } \\
\text { high wood dose but OC nature was } \\
\text { not relevant. Adsorption did not } \\
\text { change after incubation times. The } \\
\text { adsorption irreversibility decreased } \\
\text { in presence of wood for alachlor and } \\
\text { increased that of } \\
\text { linuron and metalaxyl. }\end{array}$ & $\begin{array}{c}\text { Marín-Benito et al. } \\
{[107]}\end{array}$ \\
\hline $\begin{array}{l}\text { Imazapic } \\
\text { Atrazine } \\
\text { Hexazinone } \\
\text { Diuron } \\
\text { Metribuzin }\end{array}$ & $\begin{array}{c}\text { Red Ferrusol } \\
\text { (pH 7.1, OC } 2.1 \% \text {, clay } 41 \% \text {, } \\
\text { silt } 23 \% \text { ), } \\
\text { Grey Dermosol (pH 5.7, OC } \\
0.9 \% \text {, clay } 30 \% \text {, silt } 22 \%), \\
\text { Red Kandosol (pH 6.5, OC } \\
3.5 \% \text {, clay } 22 \% \text {, silt } 8 \% \text { ) }\end{array}$ & $\begin{array}{c}\text { Eleven mill muds/ash from different } \\
\text { sugar mills (pH 6.04-7.26, OC } \\
\text { 27.7-37.8\%) } \\
\text { Mill muds/soil: } 5-25 \%\left(\mathrm{w} \mathrm{w}^{-1}\right)\end{array}$ & $\begin{array}{c}\text { Sorbent/Solution: } 1 \mathrm{~g} / 5 \mathrm{~mL} \\
0.01 \mathrm{M} \mathrm{CaCl}_{2} \\
\text { Herbicide concentration: } \\
0.5 \mathrm{mg} \mathrm{L}-1 \\
\text { Shaken: } 24 \mathrm{~h}, \mathrm{~T}: 25^{\circ} \mathrm{C} \\
\text { Analytical determination: Q-TOF }\end{array}$ & $\begin{array}{l}\text { Sorption order: diuron }>\text { atrazine }= \\
\text { metribuzin }>\text { hexazinone = imazapic } \\
\text { (consistent with herbicide properties). } \\
\text { Mill muds at } 5 \% \text { dose increased } \\
\text { herbicide retention up to tenfold. } \\
\text { Amendments reduced desorption of } \\
\text { mobile herbicides in low OC soils. }\end{array}$ & Duhan et al. [109] \\
\hline
\end{tabular}


Table 1. Cont.

\begin{tabular}{|c|c|c|c|c|c|}
\hline Pesticide & Soil Characteristics & Organic Amendment/Dose & Experimental Design & Results & Reference \\
\hline $\begin{array}{c}\text { MCPA } \\
\text { Diuron } \\
\text { Clomazone } \\
\text { Terbuthylazine }\end{array}$ & $\begin{array}{c}\text { Sandy loam soil } \\
\text { (pH 7.93, OC } 0.54 \% \text {, clay } \\
6.7 \% \text {, silt } 16.8 \%) \\
\text { Loam soil (pH } 6.77, \text { OC } \\
\text { 1.77\%, clay } 22.1 \% \text {, silt } 34.2 \%) \\
\text { Clay loam soil }(\mathrm{pH} 8.14, \mathrm{OC} \\
1.38 \% \text {, clay } 31.1 \% \text {, silt } 26.8 \%)\end{array}$ & $\begin{array}{l}\text { Mucilage extracted from chia seeds } \\
\text { (Salvia hispanica L.) } \\
\text { Organic residue/soil: } 10 \%\left(\mathrm{w} \mathrm{w}^{-1}\right)\end{array}$ & $\begin{array}{l}\text { Sorbent/Solution: } 0.5 \mathrm{~g} \text { unamended } \\
\text { or amended soil/ } 8 \mathrm{~mL} \\
\text { water solution } \\
\text { Herbicide concentration: } 1 \mathrm{mg} \mathrm{L}{ }^{-1} \\
\text { Shaken: } 24 \mathrm{~h}, \mathrm{~T}: 20^{\circ} \mathrm{C} \\
\text { Analytical determination: HPLC }\end{array}$ & $\begin{array}{l}\text { Soil porosity decreased by mucilage } \\
\text { amendment. Sorption of herbicides } \\
\text { increased in amended soils } \\
\text { (sandy-loam }<\text { loam }<\text { clay-loam). } \\
\text { Diuron recorded the highest } \mathrm{K}_{\mathrm{d}} \\
\text { value and desorption was observed } \\
\text { only for terbuthylazine. }\end{array}$ & $\begin{array}{l}\text { Marsico et al. } \\
\text { [110] }\end{array}$ \\
\hline $\begin{array}{l}\text { Dichlorvos } \\
\text { Chlorpyrifos }\end{array}$ & $\begin{array}{c}\text { Sandy soil (pH 8.52, OC 0.7\%, } \\
\text { clay + silt 9.3\%) }\end{array}$ & $\begin{array}{c}\text { Compost }(\mathrm{C}) \text { from mixed wastes }(\mathrm{pH} \\
\left.\text { 6.61, OC } 29.5 \% \text {, DOM } 354 \mathrm{mg} \mathrm{L}^{-1}\right) \\
\text { and dried goat organic manure }(\mathrm{OM}) \\
\left.\text { (pH 8.67, OC } 14.4 \% \text {, DOM } 620 \mathrm{mg} \mathrm{L}^{-1}\right) \\
\text { Organic residues/soil: } 2.5 \text { and } 5 \% \\
\left(\mathrm{w} \mathrm{w}^{-1}\right)\end{array}$ & $\begin{array}{c}\text { Sorbent/Solution: } 5 \mathrm{~g} \text { soil } / 100 \mathrm{~mL} \text { in } \\
\text { C-DOM or } 0.01 \mathrm{M} \mathrm{CaCl}_{2} \\
\text { Herbicide concentration: } \\
0.1-10 \mathrm{mg} \mathrm{L}^{-1} \text { (chlorpyrifos) } \\
0.25-100 \mathrm{mg} \mathrm{L}^{-1} \text { (dichlorvos) } \\
\text { Shaken: } 24 \mathrm{~h}, \mathrm{~T}: 25^{\circ} \mathrm{C} \\
\text { Analytical determination: GC }\end{array}$ & $\begin{array}{c}\text { C-and OM-DOM increased } \\
\text { dichlorvos sorption }(\mathrm{S}< \\
\text { S-OM-DOM }<\text { S-C-DOM) and } \\
\text { decreased chlorpyrifos sorption }(\mathrm{S}> \\
\text { S-C-DOM }>\text { S-OM-DOM). Humified } \\
\text { and aromatic nature of DOM } \\
\text { determines the interactions with } \\
\text { pesticides with different } \\
\text { hydrophobic character. }\end{array}$ & $\begin{array}{c}\text { Gaonkar et al. } \\
\text { [112] }\end{array}$ \\
\hline $\begin{array}{l}\text { Triasulfuron } \\
\text { Prosulfocarb } \\
\text { Chlorotoluron } \\
\text { Flufenacet }\end{array}$ & $\begin{array}{c}\text { Sandy loam soil (pH 7.36, OC } \\
1.20 \% \text {, clay } 17 \% \text {, silt } 25 \% \text { ) } \\
\text { Loamy sand soil (pH } 7.61, \\
\text { OC } 0.9 \% \text {, clay } 13 \% \text {, silt } 6 \% \text { ) }\end{array}$ & $\begin{array}{c}\text { Spent mushroom substrate (pH 7.9, C } \\
26.4 \% \text {, DOM 1.29\%), green compost } \\
\text { (pH 7.2, C 23.6\%, DOM 0.69\%), manure } \\
\text { (C 18.5\%, DOM 1.32\%), sewage sludge } \\
\text { (pH 7.6, C } 28.9 \% \text {, DOM 1.18\%) } \\
\text { Organic residues/soils: } 10 \%\left(\mathrm{w} \mathrm{w}^{-1}\right)\end{array}$ & $\begin{array}{c}\text { Sorbent/Solution: } 5 \mathrm{~g} \text { soil or } 0.1 \mathrm{~g} \\
\text { organic residues } / 10 \mathrm{~mL} \\
0.01 \mathrm{M} \mathrm{CaCl}_{2} \\
\text { Herbicide concentration: } \\
1-25 \mathrm{mg} \mathrm{L}^{-1} \text { (TSF, CTL, FNC) } \\
0.25-10 \mathrm{mg} \mathrm{L}^{-1}\left(100 \mathrm{~Bq} \mathrm{~mL} \mathrm{~mL}^{-1}\right)(\mathrm{PSC}) \\
\text { Shaken: } 24 \mathrm{~h}, \mathrm{~T}: 20^{\circ} \mathrm{C} \\
\text { Analytical determination: HPLC/MS } \\
\text { and Liquid scintillation }\end{array}$ & $\begin{array}{c}\text { Highest adsorption for prosulfocarb } \\
\text { (lowest water solubility and highest } \\
\mathrm{K}_{\mathrm{ow}} \text { ) in all materials. Aliphatic and } \\
\text { aromatic structures optimize } \\
\text { adsorption and O-alkyl and N-alkyl } \\
\text { groups enhance desorption } \\
\text { hysteresis. }\end{array}$ & $\begin{array}{l}\text { García-Delgado } \\
\text { et al. [114] }\end{array}$ \\
\hline
\end{tabular}


Table 2 includes a summary of the main results obtained from recent literature that has evaluated pesticide mobility in amended soil, including the effects of DOM extracted from organic residues. These studies have been reported for compounds with different properties, and they have generally been conducted under laboratory conditions. These laboratory assays are usually based on two types of soil columns: undisturbed soil cores taken directly in the field to preserve the soil macrostructure within the soil profile [120,121], or packed soil columns [78,96]. The effect of organic amendments on the leaching of pesticides is assessed in both types of columns after washing with a continuous flow of water or aqueous solution of $\mathrm{CaCl}_{2}$ (saturated flow) or a discontinuous flow (saturated/non-saturated flow). Several pesticide leaching studies under different flow regimes have been conducted with columns of soils amended with a wide variety of organic residues, such as olive mill waste [122,123], SMS [96], sheep manure, spent coffee grounds, composted pine bark, and coir [124], BC [125-127], manure and fly ash [128,129], winery vermicompost [130], agro-industrial and composted organic wastes [131], or GC [132]. In general, these studies have revealed a decrease in pesticide leaching because of enhanced pesticide sorption due to the influence of the organic amendments in soils.

The effects of $\mathrm{BC}$ as a soil amendment for reducing the movement of pesticides to surface and ground waters has been evaluated together with the effects of increasing pesticide sorption, as previously indicated. Delwiche et al. [133] and Deng et al. [104] have reported a sharp decrease in atrazine leaching after amending the soil with BC from pine chip and from cassava residues, respectively. The presence of more macropores in the $\mathrm{BC}$ structure was indicated as being responsible for this decreased atrazine leaching, while pore deformation in BC decreased pesticide leaching in homogenized soil [134]. Tang et al. [135] have reported that $\mathrm{BC}$ from bamboo greatly reduces organochlorine pesticide leaching (by up to $65 \%$ ), and Wang et al. [136] have reported that $60 \%$ of sulfamethoxazole is lost/leached in unamended soil and reduced to $2-14 \%$ after applying BC. Mendes et al. $[105,106]$ have recently studied the high potential of $\mathrm{BC}$ from cow bone to adsorb and reduce/minimize the desorption of the herbicides hexazinone, metribuzin, quinclorac, aminocyclopyrachlor, and mesotrione. An efficient decrease in their leaching in BC-amended soils has been identified even at relatively low application rates.

The simultaneous effect of other organic residues on different processes affecting pesticide dynamics in amended soils, including leaching, has also been also reported. Pérez-Lucas et al. [137] have assessed the effect of two different organic residues (composted sheep manure (EC) and coir (CR)) on the sorption, persistence, and mobility of one herbicide (alachlor (AL)) and two insecticides (chlorfenvinphos $(\mathrm{CF})$ and chlorpyrifos (CP)) with different physicochemical properties. The incorporation of organic wastes in the soil significantly increases the sorption of all the pesticides (especially CF) and decreases their degradation. Leaching experiments conducted in disturbed soil columns have shown a rapid leaching for AL through the unamended soils and a lower retention than for organophosphate insecticides. CF and CP record a significantly lower leaching rate than AL (especially CP) and lower concentrations in leachates. There is a clear decrease in the amount recovered in leachates in the amended soils, except for $\mathrm{CP}$, whose recoveries hardly change. By contrast, Jiang et al. [84] have investigated the effects of sugarcane bagasse compost (SBC) and chicken manure compost (CMC) on the adsorption-desorption, leaching and bioavailability in soil of the fungicide penconazole under laboratory conditions. The autoclave-treated SBC or CMC applied at $2.5 \%$ and $5.0 \%\left(\mathrm{w} \mathrm{w}^{-1}\right)$ promoted the adsorption capacity of soils for penconazole, whereas desorption was radically reduced, with the effect being enhanced by the higher amount of organic amendment (Table 1). Furthermore, column leaching experiments indicated that SBC or CMC limited the transport of penconazole through the soil columns, decreasing its concentration in the soil leachate. These results have revealed major changes in bioavailability experiments under SBC or CMC application, showing that the organic amendments influence the uptake and translocation of penconazole in plants. 
The effects of unamended and amended soil properties on the leaching of certain pesticides, such as clothianidin, have been reported. Samarendra-Singh et al. [138] have studied this insecticide's leaching potential through packed columns with or without farmyard manure (FYM) in a clay loam and a sandy loam soil. The results indicate that the insecticide has less potential to leach in soils with a higher percentage of clay and OC. Likewise, clothianidin may sink to a lower soil profile in the highly porous sandy loam soil under high rainfall conditions, and may contaminate groundwater, so the use of FYM was a good option to reduce its leaching.

Some leaching studies have been conducted under dynamic conditions to explore, together with pesticide characteristics, the changes in their mobility and the potential contamination of groundwater in a more realistic way [96]. Experiments performed under saturated flow conditions simulate the worst-case scenario $[125,129,139]$, while experiments performed under conditions of saturated-unsaturated flow, such as precipitation and irrigation events, simulate real field conditions [123,124]. In general, mobility studies in amended soils have been performed under saturated or unsaturated flow regimes, with fewer studies under both flow conditions or under different states of aging pesticides in amended soils in spite of their importance for determining pesticides' impact on mobility [96,120,132]. Álvarez-Martín et al. [96] have reported the leaching of two fungicides, tebuconazole (non-polar) and cymoxanil (polar), in packed soil columns, evaluating the influence of SMS at different rates $\left(5 \%\right.$ and $\left.50 \% \mathrm{w} \mathrm{w}^{-1}\right)$ as an amendment, and saturated and saturated-unsaturated water flows as leaching regimes. SMS decreased the leaching of tebuconazole in the amended soil under both leaching regimes, while it did not do so for cymoxanil under saturated flow. However, the leached amounts of both fungicides decreased when a saturated-unsaturated flow was applied in SMS-amended soils. A significant decrease in leaching was also observed after fungicide incubation in the column, especially in soil + SMS 50\% when both flows were applied. A high SMS dose decreases fungicide leaching but may increase its adsorption in a non-extractable form over time, reducing its bioavailability (non-polar fungicide) or mineralization (polar fungicide). Similarly, Barba et al. [132] have assessed the effects of GC in the leaching of the herbicide prosulfocarb through packed soil columns, with saturated or saturated-unsaturated flows as irrigation regimes and different herbicide incubation times after its application. The amount of herbicide retained in the column was higher in the amended soil under saturated flow than in the unamended one, indicating a stronger interaction between the herbicide and the amended soil. However, the total amounts retained under saturated-unsaturated flow were similar in all the treatments. The incubation time did not significantly affect herbicide retention, but it considerably increased the mineralized amount under saturated flow.

Other investigations in the literature have focused on DOM's impact on pollutant solubilization. It is often the case that not only the quantity but also the quality of the DOM is a principal factor influencing the potential enhancement of a pesticide's solubility, besides its physicochemical characteristics [91,140]. Chabauty et al. [141] have studied the effects of DOM from the top soil on the leaching of two pesticides, isoproturon and epoxiconazole, and two pharmaceutical compounds, ibuprofen and sulfamethoxazole, in cultivated soils receiving repeated application of combined compost consisting of green wastes and sewage sludge (SGW). Percolation experiments were performed in undisturbed soil columns with and without DOM from two soils to characterize DOM's transport and dynamics in the Bt horizons, as well as its effect on water transport and the interactions between organic pollutants and deeper soil horizons. The illuviated Bt layer may act alternatively as a DOM source and sink DOM according to the quality of the percolating solutions. DOM significantly increases the mobility of all the organic contaminants, but the effects fluctuate according to the molecules' hydrophobic nature and ionic character. 
Table 2. Leaching of pesticides in amended soils.

\begin{tabular}{|c|c|c|c|c|c|}
\hline Pesticide/Dose & $\begin{array}{c}\text { Soil } \\
\text { Characteristics }\end{array}$ & Organic Amendment/Dose & Experimental Design & Results & Reference \\
\hline $\begin{array}{c}\text { Alachlor } \\
\text { Chlorfenvinphos } \\
\text { Chlorpyrifos } \\
\text { C } 150 \mu \mathrm{g} \mathrm{mL} L^{-1}\end{array}$ & $\begin{array}{c}\text { Hypercalcic calcisol (pH 7.9, } \\
\text { OC } 0.9 \% \text {, clay } 29.1 \% \text {, silt } 33.4 \% \text { ) }\end{array}$ & $\begin{array}{c}\text { Composted sheep manure } \\
(\mathrm{EC})(\mathrm{pH} 8.3, \mathrm{OC} 264.9 \mathrm{~g} \\
\left.\mathrm{kg}^{-1}\right) \text { and Coir }(\mathrm{CR})(\mathrm{pH} 7.5 \\
\left.\text { OC } 442 \mathrm{~g} \mathrm{~kg}^{-1}\right) \\
\text { Organic residues/soils } 1 \%\end{array}$ & $\begin{array}{l}\text { Packed columns }(5 \mathrm{~cm} \text { i.d. } \times 30 \mathrm{~cm} \text { length }) \\
\text { of } \mathrm{S}, \mathrm{S}+\mathrm{EC} \text { and } \mathrm{S}+\mathrm{CR} \text {. Saturation with } \\
\mathrm{CaCl}_{2} \text { solution }(0.01 \mathrm{M}) \text { at maximal WHC. } \\
\text { Drainage for } 24 \mathrm{~h} \text {. Determination of PVs } \\
(\mathrm{mL}) \text { of soil columns. Application of } \\
\text { pesticide }(1 \mathrm{~mL}) \text {. Leaching volume } 750 \mathrm{~mL} \\
\text { of } \mathrm{CaCl}_{2} \text { solution }(0.01 \mathrm{M}) \text { for } 10 \text { days. } \\
\text { Leached volume } / \text { day: } 50 \mathrm{~mL} \\
\text { Analytical determination: } \mathrm{GC} / \mathrm{MS}\end{array}$ & $\begin{array}{l}\text { Highest leaching for alachlor. } \\
\text { Chlorfenvinphos and chlorpyrifos had } \\
\text { low leachability through soil columns } \\
\text { (related with their low water } \\
\text { solubility). Both compounds were } \\
\text { recovered in higher proportions from } \\
\text { the soil column than alachlor. }\end{array}$ & $\begin{array}{l}\text { Pérez-Lucas et al. } \\
{[137]}\end{array}$ \\
\hline $\begin{array}{l}\text { Penconazole } \\
\text { C } 500 \mu \mathrm{g} \mathrm{mL}^{-1}\end{array}$ & $\begin{array}{l}\text { Sandy soil (pH } 6.20, \text { OC } 0.56 \% \text {, } \\
\text { clay } 14.92 \% \text {, silt } 33.44 \%)\end{array}$ & $\begin{array}{c}\text { Sugarcane bagasse compost } \\
\text { (SBC) (pH 6.32, OC 56.16\%), } \\
\text { chicken manure compost } \\
\text { (CMC) (pH 6.27, OC } 27.41 \%) \text {. } \\
\text { Organic residues / soil: } 2.5 \% \\
\left.\text { and 5.0\% ( } \mathrm{w} \mathrm{w}^{-1}\right)\end{array}$ & $\begin{array}{l}\text { Glass columns }(4.8 \mathrm{~cm} \text { i.d. } \times 32 \mathrm{~cm} \text { length). } \\
\text { Pre-saturation with } \mathrm{CaCl}_{2} \text { solution }(0.01 \\
\mathrm{M})(500 \mathrm{~mL}) \text { for } 16 \mathrm{~h} \text {. Application of } \\
\text { pesticide }(1 \mathrm{~mL}) \text {. Leaching volume } 2500 \\
\text { mL of } \mathrm{CaCl}_{2} \text { solution }(0.01 \mathrm{M}) \text { for } 50 \mathrm{~h} \text {. } \\
\text { Leached volume } 50 \mathrm{~mL} \text { fractions. } \\
\text { Extraction of pesticide from soil column } \\
\text { (each } 5 \mathrm{~cm}) \text {. Analytical determination: } \\
\text { UPLC/TUV }\end{array}$ & $\begin{array}{l}\text { SBC and CMC reduced penconazole } \\
\text { leaching by decreased soil porosity } \\
\text { and increased adsorption by amended } \\
\text { soils. Inhibition of leaching by CMC } \\
\text { was lower than by SBC (due to } \\
\text { differences in sorption capacity). } \\
\text { On the contrary, its content was higher } \\
\text { in SBC-soil than in CMC-soil columns. }\end{array}$ & Jiang et al. [84] \\
\hline $\begin{array}{l}\text { Clothianidin } \\
\text { C } 10 \mu \mathrm{g} \mathrm{mL}^{-1}\end{array}$ & $\begin{array}{l}\text { Clay loam S1 (pH 5.06, OC } \\
0.95 \% \text {, clay } 30.4 \% \text {, silt } 36.5 \%) \\
\text { Sandy loam S2 (pH } 8.41, \text { OC } \\
0.29 \% \text {, clay } 10.4 \% \text {, silt } 18.1 \%)\end{array}$ & $\begin{array}{l}\text { Farm yard manure }(\mathrm{FYM}) \\
(\mathrm{pH} \text { 6.6, OC } 23.7 \%) \\
\text { Organic residue/soil: } 2.5 \% \\
\left(\mathrm{w} \mathrm{w}^{-1}\right)\end{array}$ & $\begin{array}{l}\text { Packed soil columns }(2.1 \mathrm{~cm} \text { i.d. } \times 50 \mathrm{~cm} \\
\text { length) }(200 \mathrm{~g} \text { S or } \mathrm{S}+\mathrm{FYM}) . \\
\text { Pre-saturation overnight in water. } \\
\text { Leaching flow: } 400 \mathrm{~mL} \text { of water }(1156 \mathrm{~mm} \\
\text { of rainfall) as continuous flow, or amounts } \\
\text { of } 20,40,80 \text { and } 160 \mathrm{~mL} \text { of water }(51.92, \\
103.85,207.71 \text { and } 415.42 \mathrm{~mm} \text { of rainfall) as } \\
\text { discontinuous flow). Extraction of } \\
\text { pesticide from column soil (each } 5 \mathrm{~cm}) . \\
\text { Analytical determination: HPLC/PDA }\end{array}$ & $\begin{array}{l}\text { Clothianidin leaching was minimized } \\
\text { in S1 compared to S2 after FYM } \\
\text { application. Both soils concentrated } \\
\text { maximum residue with or without } \\
\text { FYM in } 0-20 \mathrm{~cm} \text { soil depth. } \\
\text { Clothianidin did not leach under } \\
\text { different and discontinuous } \\
\text { flow conditions. }\end{array}$ & $\begin{array}{l}\text { Samarendra- } \\
\text { Singh et al. } \\
\text { [138] }\end{array}$ \\
\hline
\end{tabular}


Table 2. Cont.

\begin{tabular}{|c|c|c|c|c|c|}
\hline Pesticide/Dose & $\begin{array}{c}\text { Soil } \\
\text { Characteristics }\end{array}$ & Organic Amendment/Dose & Experimental Design & Results & Reference \\
\hline 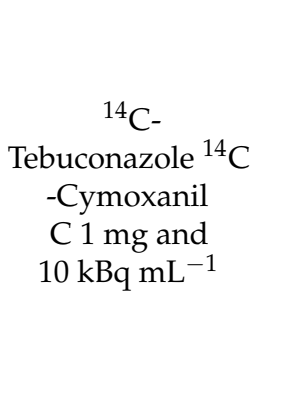 & $\begin{array}{c}\text { Sandy clay loam soil } \\
\text { (pH } 7.52, \text { OC } 0.67 \% \text {, clay } 21.1 \% \text {, } \\
\text { silt } 11.9 \% \text { ) }\end{array}$ & $\begin{array}{l}\text { Spent mushroom substrate } \\
\text { (SMS) (pH 6.97, OC 24.5\%, } \\
\text { DOM 1.91\%) } \\
\text { Organic residue/soil: } 5 \% \\
\text { and } 50 \%\left(\mathrm{w} \mathrm{w}^{-1}\right)\end{array}$ & $\begin{array}{l}\text { Packed soil columns }(3 \mathrm{~cm} \text { i.d. } \times 25 \mathrm{~cm} \\
\text { length) }(100 \mathrm{~g} \mathrm{~S}, \mathrm{~S}+\mathrm{SMS} 5 \text { and } \mathrm{S}+\mathrm{SMS} 50) \text {. } \\
\text { Chloride as an ion tracer. Leaching flow: } \\
500 \mathrm{~mL} \text { of } \mathrm{CaCl}_{2} \text { solution }(0.01 \mathrm{M})(12 \mathrm{PV}) \text {. } \\
\text { Washing flow regimes: saturated } \\
\text { (continuously pumped for } \approx 8 \mathrm{~h} \text { ) and } \\
\text { saturated-non saturated }(20 \text { days, } 25 \\
\mathrm{mL} / \text { day). Columns nonincubated and } \\
\text { incubated over } 30 \text { days. Analytical } \\
\text { determination: Liquid scintillation }\end{array}$ & $\begin{array}{l}\text { Amendments decreased leaching of } \\
\text { tebuconazole under different flow } \\
\text { conditions, and decreased leaching of } \\
\text { cymoxanil under } \\
\text { saturated-unsaturated flow. Ageing } \\
\text { favored retention decreasing } \\
\text { tebuconazole leaching or cymoxanil } \\
\text { mineralization. }\end{array}$ & $\begin{array}{l}\text { Álvarez-Martín } \\
\text { et al. [96] }\end{array}$ \\
\hline $\begin{array}{l}{ }^{14} \text { C-Prosulfocarb } \\
\text { C } 1 \text { mg and } 10 \\
\text { kBq mL } \\
\text { (2.5 times the } \\
\text { agronomic dose) }\end{array}$ & $\begin{array}{l}\text { Sandy clay loam soil (pH } 7.35 \\
\text { OC } 1.30, \text { clay } 17 \% \text {, silt } 25 \% \text { ) }\end{array}$ & $\begin{array}{c}\text { Green compost (GC) }(\mathrm{pH} \\
\text { 7.20, OC } 24.1 \%, \mathrm{DOM} \\
0.703 \%) \\
\text { Organic residue/soil: } \\
20 \% \mathrm{w} \mathrm{w}^{-1}\left(180 \mathrm{tha}^{-1}\right)\end{array}$ & $\begin{array}{c}\text { Packed soil columns }(3 \mathrm{~cm} \text { i.d. } \times 25 \mathrm{~cm} \\
\text { length) }(100 \mathrm{~g} \text { S and S + GC). Chloride as } \\
\text { an ion tracer. Leaching flow: } 500 \mathrm{~mL} \text { of } \\
\mathrm{CaCl}(0.01 \mathrm{M})(12 \mathrm{PV}) \text { under saturated } \\
\text { flow and under saturated-unsaturated } \\
\text { flow ( } 20 \mathrm{~mL} / \text { day). Columns } \\
\text { nonincubated and incubated over } 28 \text { days. } \\
\text { Analytical determination: } \\
\text { Liquid scintillation }\end{array}$ & $\begin{array}{l}\text { Leached amounts decreased in S and S } \\
+ \text { GC columns after incubation. } \\
\text { Retained amounts were lower in S than } \\
\text { in S + GC columns under saturated } \\
\text { flow. Prosulfocarb was retained in the } \\
\text { first segment of columns under all } \\
\text { conditions. Herbicide incubation } \\
\text { increased the mineralized amount } \\
\text { under saturated flow. }\end{array}$ & Barba et al. [132] \\
\hline $\begin{array}{l}\text { Isoproturon } \\
\text { C } 47-59 \mu \mathrm{g} \mathrm{L}^{-1} \\
\text { Epoxiconazole } \\
\text { C 89.6-117 } \mathrm{gL}^{-1} \\
\quad \text { Ibuprofen } \\
\text { C 64.7-94.4 } \mu \mathrm{g} \mathrm{L}^{-1} \\
\text { Sulfamethoxazole C } \\
\text { 39.0-51.9 } \mathrm{g} \mathrm{L}^{-1}\end{array}$ & $\begin{array}{c}\text { Loamy soil } \\
\text { Ap }(0-28 \mathrm{~cm}) \\
(\mathrm{pH} 7.0, \mathrm{OC} 0.23 \% \text {, clay } 14.6 \% \text {, } \\
\text { silt } 79 \%) \\
\text { Bt }(60-90 \mathrm{~cm})(\mathrm{pH} 7.5, \mathrm{OC} \\
1.02 \% \text {, clay } 31.1 \% \text {, silt } 64.6 \%)\end{array}$ & $\begin{array}{c}\text { Combined compost of } \\
\text { sewage sludges and green } \\
\text { wastes (SWG) }(\mathrm{pH} 6.9, \mathrm{OC} \\
\left.15.8 \mathrm{~g} \mathrm{~kg}^{-1}\right)\end{array}$ & $\begin{array}{l}\text { Undisturbed soil cores }(14 \mathrm{~cm} \text { i.d. } \times 30 \mathrm{~cm} \\
\text { length) with } 5300 \mathrm{~cm}^{3} \text { volume. Bromide as } \\
\text { ion tracer. } \\
\text { Leaching experiments with synthetic } \\
\text { water, DOM of soil or soil + SWG. } \\
\text { Unsaturated steady-state flow regime of } \\
\text { two consecutive rainfalls of } 1.76 \mathrm{~mm} \mathrm{~h}^{-1} \\
\text { intensity and separated by a } 1-\text { week flow } \\
\text { interruption on triplicated cores for } \\
28 \text { days. } \\
\text { Analytical determination: } \\
\text { UHPLC/MS/MS }\end{array}$ & $\begin{array}{l}\text { DOM increased mobility of Br- and all } \\
\text { pollutants. The mobility increase was } \\
\text { greater for more hydrophobic } \\
\text { compounds (epoxiconazole and } \\
\text { ibuprofen). DOM can also enhance the } \\
\text { transport of anionic molecules but for } \\
\text { these compounds also depend on their } \\
\text { affinity for the soil matrix including } \\
\text { soil solution composition and its } \mathrm{pH} \text {. }\end{array}$ & $\begin{array}{c}\text { Chabauty et al. } \\
\text { [141] }\end{array}$ \\
\hline
\end{tabular}




\subsection{Effect of Organic Residues on Pesticide Dissipation}

Pesticide degradation refers to its breakdown into environmentally stable and compatible substances, and together with adsorption it is the main process that determines its fate in soil and water environments [142]. Data on the degradation kinetics of pesticides are necessary for characterizing their concentration over time and evaluating their persistence when applied in the field, as well as their potential threat to both target and non-target species.

Pesticide degradation in soils is informed by abiotic and biotic factors. Abiotic degradation involves hydrolysis and photodegradation, while biotic degradation involves the reactions of microorganisms (mainly bacteria and fungi). Microbial degradation is generally considered to be mainly responsible for pesticide breakdown, resulting in less toxic compounds and affecting even the most persistent pesticides [143-146]. The level of biodegradation can fluctuate from minor changes, without significantly compromising a pesticide's chemical and toxicological properties, to the compound's complete mineralization. In general, soil microorganisms use pesticides as a direct source of energy and nutrients [75], or through co-metabolism [147]. The main factors affecting pesticide degradation include different environmental aspects (soil type, soil OM, irrigation, weather -mainly temperature and precipitation), pesticide formulation (individual or combined compounds), and application method (single or repeated application) [148].

The control of the pesticide adsorption-desorption processes in soil by SOM and DOM from the aforementioned organic amendments may affect their dissipation (Figure 1). In general, SOM favors the adsorption of pesticides, and this process controls their degradation, as it determines their availability in the soil. Adsorption decreases their bioavailability for degradation by soil microorganisms and the rate at which they are degraded $[75,83,149]$. Organic amendments could therefore modify the persistence and dissipation of pesticides in soils by enhancing their adsorption as a consequence of increasing soil OC [77-79]. In some cases, organic materials have decreased the half-life of a pesticide, while in others there has been an increase or even no effect at all [79,150,151]. In turn, DOM may also affect the degradation and mineralization kinetics of pesticides by (i) decreasing pesticide adsorption and enhancing its bioavailability or by contrast, (ii) increasing the adsorption of the compounds and decreasing their bioavailability according to some of the different processes explained in Section 3.1 [94,101,140,152]. DOM's influence in pesticide biodegradation depends on its source, nature and concentration, and therefore on soil type and pesticide characteristics [153]. Simultaneously, OM, nutrients, and sometimes the microorganisms in the amendment may modify/increase the activity of soil microbial communities, and the stimulation of microbial activity may increase pesticide degradation [154-156]. In fact, most of the organic residues allow the growth of fungi, which produce extracellular ligninolytic enzymes that promote pesticide degradation [157].

Table 3 includes a summary of the main results reported in recent experiments carried out under laboratory conditions, evaluating the effect that the application of organic residues has on the bioavailability, degradation, dissipation and/or persistence of pesticides in amended soils. In general, different factors have been considered, such as soil amendments of different nature, origin, rates or incubation times, and pesticides with different characteristics and behavior.

$B C^{\prime}$ 's effect on the dissipation of pesticides has been widely investigated, together with its impact on the adsorption-desorption and leaching processes. Yavari et al. [146] have studied the effects that two BCs obtained from the empty fruit bunch (EFB) of oil palm and rice husk (RH) have on the photolysis and biodegradation of the herbicides imazapic, imazapyr, and their combination $\left(\mathrm{OnDuty}^{\circledR}\right)$. Polar herbicides are resistant to hydrolysis degradation, and photolysis rates are reduced significantly in the presence of $\mathrm{BC}$. EFB-BC had a greater effect on the increase in $\mathrm{DT}_{50}$ due to its chemical composition and surface functional groups. In contrast to photolysis, the biodegradation of imidazolinones is significantly accelerated in the presence of both $\mathrm{BCs}$, although $\mathrm{RH}-\mathrm{BC}$ has a greater impact. The effects of other BCs derived from rice straw (RS), corn straw (CS), chicken 
manure (CM) and tire rubber (TR) on the dissipation of the fungicide cyazofamid and its metabolite CCIM (4-chloro-5-p-tolylimidazole-2-carbonitrile) have been assessed by Tang et al. [158]. Cyazofamid dissipation is either accelerated or depressed, depending on BC type, application rate, and soil moisture. Adsorption, hydrolysis and microbial degradation are all involved in cyazofamid dissipation. CM- and CS-BC enhance fungicide dissipation through the biodegradation related to changes in the microbial community. The residual amounts of metabolite CCIM increase by 8-15 times after BC application, regardless of BC type and cyazofamid dissipation. Tang et al. [158] provided new insights into $\mathrm{BC}$ application for soil remediation and highlighted the potential risk of the build-up of metabolites in BC-amended soil, especially when the metabolites have higher toxicities than the parent compound.

The impact on pesticide degradation of other organic amendments applied to soils has been investigated for the herbicide imazapic under various environmental conditions, including temperature, soil moisture, and soil $\mathrm{pH}$ [159]. CM and biogas slurry (BS) have been applied at different rates, and herbicide degradation has been studied at different temperatures $\left(15,25\right.$ and $\left.35^{\circ} \mathrm{C}\right)$, soil moisture content $(15 \%, 40 \%, 60 \%$ and $90 \%)$, and soil $\mathrm{pH}$ (6.0, 7.0 and 8.0). The imazapic degradation rate increases with higher temperature, soil pH, and soil moisture, and decreases with OM content. A long residual period of herbicide has been observed, and microbial degradation has been proposed as the primary degradation mechanism (high temperatures and moist soil conditions favor microbial activity and accelerate imazapic degradation). Microbial degradation has been correlated with soil properties and adsorption. The combined effect of temperature and organic amendments on the degradation of chlorotoluron and flufenacet has also been studied by Marín-Benito et al. [160]. They have assessed herbicide degradation kinetics at two different temperatures, 6 and $16^{\circ} \mathrm{C}$, in an unamended soil and one amended with SMS and GC, and the formation of the main metabolites of both herbicides over degradation time. The degradation of flufenacet, the more hydrophobic herbicide, was slower than chlorotoluron in all the treatments. Nonetheless, the addition of SMS and GC to the soil decreases their degradation rates because of their higher sorption and lower bioavailability. This impact depends on the herbicide and incubation temperature. Faster degradation has been confirmed for both herbicides at $16{ }^{\circ} \mathrm{C}$, possibly due to increased microbiological activity with the higher temperature, and a significant presence of metabolites has been observed in all the soil treatments. The effect of GC as soil amendment on the dissipation of the herbicide prosulfocarb $\left({ }^{14} \mathrm{C}\right.$-labeled) has also been assessed by Barba et al. [161], determining the dissipation mechanisms and the total mass balance of herbicide applied at two rates (4 and $10 \mathrm{mg} \mathrm{kg}^{-1}$ ). The herbicide records higher bioavailability and faster dissipation in the unamended soil than in the amended one due to its lower sorption, irrespective of the dose applied. A temporal decrease in extractable amounts has been observed in all the soil treatments, revealing herbicide aging over time. Prosulfocarb mineralization and non-extractable residues record a slow increase over incubation time. At the end of the dissipation period, the total ${ }^{14} \mathrm{C}$ mass balance is approximately $60-70 \%$ under all conditions, indicating that part of the herbicide has probably been lost through volatilization. Hence, GC influences herbicide bioavailability by decreasing its biodegradation.

As regards the impact that the pesticide application method (single or repeated) has on pesticide dissipation in the soil, it has been frequently reported in unamended soils with significant conclusions. On the one hand, the repeated application of pesticides to the same soil over a long period is a common agricultural practice, and it can influence pesticide dissipation, accelerating biodegradation by adapted soil microorganisms, which may reduce or even eliminate the pesticide's efficacy for controlling the target pest, disease or weed $[162,163]$. On the other hand, pesticide residues could remain in the soil after repeated applications, affecting soil microbial function and structure. In some cases, repeated application may have a detrimental effect on the microbial community by degrading the pesticide, significantly compromising its performance [163,164]. In amended soils, however, laboratory studies on pesticide dissipation have been conducted mainly with a 
single application of just one compound $[29,165,166]$, while only a handful of studies have reported the effects that repeated and/or combined pesticide applications have on their dissipation in amended soils. Pose-Juan et al. [167] have studied the effects of two repeated applications of mesotrione, pethoxamid, and triasulfuron on their dissipation rates in unamended soil and soil amended with GC or SS. Repeated herbicide application in soils has prompted dissipation effects that differ to those observed with only a single application. For mesotrione, this repeated application has an inhibitory effect on its dissipation rate in all the soils studied, and the herbicide could become more persistent or increase its accumulation in amended soils. However, repeated applications of pethoxamid and triasulfuron accelerate their dissipation in amended soils. The formation of bound residues over time has been suggested as the process responsible for an apparent dissipation, decreasing the bioavailability of the compound to be degraded. The dissipation mechanism of these herbicides has been supported by the adsorption constants determined, indicating the highest adsorption by amended soils (Table 1).

\section{Conclusions}

This review evaluates how the dynamics of pesticides in soil is modified by the application of organic residues as soil amendments. By focusing on the main processes (adsorption-desorption, dissipation and leaching) that govern the fate of pesticides in soils, the review highlights the complexity of extrapolating the behavior from some pesticides to others in the presence of different organic residues, even in the same soil. Multiple reasons intrinsically related to soil, pesticide and organic residue properties and composition limit this extrapolation. However, all these factors and the combinations tested at laboratory scale constitute a major limitation. Working at laboratory scale represents the platform, and first step of any subsequent successful research because it involves doing so under controlled conditions oriented towards target variables. This allows analyzing the impact of the application of organic amendments to soils on an individual basis, influencing the environmental fate of pesticides and testing different variables to optimize the coexistence of both agricultural practices.

\section{Future Perspectives on the Application of Pesticides and Organic Amendments in Soils}

Once the influence of organic amendments on an individual pesticide has been studied and documented by laboratory assays, the next step should be to extend these studies to field scale under real conditions. This will allow considering additional factors such as the undisturbed soil structure, precipitation, temperature, irrigation, or the presence of crops affecting the dynamics of pesticides through the uptake process or simply controlling for water dynamics. A holistic view jointly evaluating the different pesticide processes and their interactions affected by the application of the organic amendments will contribute to a more complete and more effective interpretation of the environmental fate of pesticides in amended soils. Despite the potential relevance of the results obtained in this kind of study, only a few assays combine pesticides-organic amendments at field scale [149,168-170].

Finally, the third step prior to the use of organic residues as soil amendments from a beneficial agronomic point of view that avoids compromising the sustainability of soil and water resources would be to simulate the behavior of pesticides in amended soil scenarios. There is an important gap in this research field, as evidenced by the scarce studies reported in the literature, especially using the pesticide fate models usually applied in a regulatory context [171-173].

The optimization of the use of pesticides together with organic amendments in soil therefore calls for field studies to assess pesticide behavior under different amended soil scenarios, together with models for simulating and predicting pesticides' environmental fate as future perspectives. 
Table 3. Dissipation of pesticides in amended soils.

\begin{tabular}{|c|c|c|c|c|c|}
\hline Pesticide & $\begin{array}{c}\text { Soil } \\
\text { Characteristics }\end{array}$ & Organic Amendment/Dose & Experimental Design & Results & Reference \\
\hline $\begin{array}{l}\text { Imazapic } \\
\text { Imazapyr } \\
\text { mixture of them } \\
\left(\text { Onduty }{ }^{\circledR}\right)\end{array}$ & $\begin{array}{l}\text { Clay loam soil } \\
\text { (pH } 6.36, \text { OC } 0.99 \% \text {, } \\
\text { clay } 37.9 \% \text {, silt } \\
21.58 \% \text { ) }\end{array}$ & $\begin{array}{l}\text { Biochar from fruit bunch of oil } \\
\text { palm (EFB) (pH 6.13, C 58.60\%) and } \\
\text { rice husk (RH) (pH 6.32, C } 48.26 \%) \\
\text { Biochar/soil: } 1.0 \%\left(\mathrm{w} \mathrm{w}^{-1}\right)\end{array}$ & $\begin{array}{c}\text { Hydrolysis: Solution/herbicide concentration } \\
50 \mathrm{~mL} / 10 \mathrm{mg} \mathrm{L}^{-1}, \mathrm{pH} 3,7 \text { and } 9 \\
\text { Photodegradation: Soil/herbicide } \\
30 \mathrm{~g} / 0.2 \mu \mathrm{g} \mathrm{g}^{-1} \text {. } \\
\text { Biodegradation: Soil/herbicide } 10 \mathrm{~g} / 0.2 \mu \mathrm{g} \mathrm{g}^{-1} \text {. } \\
\text { T: } 25^{\circ} \mathrm{C} \text {. Relative humidity: } 85 \% \\
\text { Time up to } 70 \text { days. } \\
\text { Analytical determination: HPLC }\end{array}$ & $\begin{array}{l}\text { All herbicides were resistant to } \\
\text { hydrolysis degradation. Photolysis } \\
\text { rates of herbicides were reduced by } \\
\text { use of biochar, particularly EFB. } \\
\text { Biodegradation of herbicides } \\
\text { accelerated significantly by the use } \\
\text { of biochars. }\end{array}$ & $\begin{array}{c}\text { Yavari et al. } \\
\text { [146] }\end{array}$ \\
\hline $\begin{array}{l}\text { Cyazofamid } \\
\text { Metabolite } \\
\text { CCIM } \\
\text { (4-chloro-5-p- } \\
\text { tolylimidazole- } \\
\text { 2-carbonitrile) }\end{array}$ & $\begin{array}{l}\text { Silty soil } \\
\text { (pH 7.14, OC } 0.71 \% \text {, } \\
\text { clay } 8.25 \% \text {, silt } \\
85.55 \%)\end{array}$ & $\begin{array}{c}\text { Biochars from rice straw }(\mathrm{RS})(\mathrm{pH} \\
\text { 9.87, C 36.58\%), corn straw }(\mathrm{CS}) \\
(\mathrm{pH} 9.97, \mathrm{C} 57.33 \%) \text {, chicken } \\
\text { manure }(\mathrm{CM})(\mathrm{pH} 8.16, \mathrm{C} 27.73 \%) \\
\text { and tire rubber }(\mathrm{TR})(\mathrm{pH} 8.82, \mathrm{C} \\
74.60 \%) \\
\text { Biochar } / \text { soil: } 3 \%\left(\mathrm{w} \mathrm{w}^{-1}\right)\end{array}$ & $\begin{array}{c}\text { Soil samples: } 20.6 \mathrm{~g} \\
\text { Pesticide applied: } 2.5 \mathrm{mg} / \mathrm{kg} \text { of dry soil } \\
\text { Soil moisture content: } 40 \% \mathrm{WHC} \\
\text { Incubation } \mathrm{T}: 25^{\circ} \mathrm{C} \\
\text { Sampling times up to } 40 \text { days } \\
\text { Analytical determination: HPLC/MS/MS }\end{array}$ & $\begin{array}{c}\text { Cyazofamid dissipation order: CS > RS } \\
\text { > CM } \\
\text { TR depressed cyazofamid dissipation. } \\
\text { Adsorption, hydrolysis and microbial } \\
\text { degradation were all involved in its } \\
\text { dissipation. CM and CS enhanced the } \\
\text { cyazofamid dissipation by } \\
\text { biodegradation. CCIM residual } \\
\text { increased by 8-15 times after biochar } \\
\text { application, regardless of biochar type. }\end{array}$ & Tang et al. [158] \\
\hline Imazapic & $\begin{array}{c}\text { Silty soil } \\
\text { (pH } 8.1, \text { OM } 0.55 \% \\
\text { clay } 9.1 \% \text {, silt } 69.1 \%)\end{array}$ & $\begin{array}{c}\text { Chicken manure (pH 7.1, OM } \\
21.5 \%) \\
\text { biogas slurry (pH 7.0, OM 20.1\%) } \\
\text { CM/soil: } 2.1-16 \% \text {; BS/soil: } \\
\text { 3.6-0.9\% }\end{array}$ & $\begin{array}{c}\text { Soil samples: } 1000 \mathrm{~g} \\
\text { Pesticide applied: } 20 \mathrm{~mL}\left(50 \mathrm{mg} \mathrm{L}^{-1}\right) \\
\text { Incubation T: } 15,25 \text { and } 35^{\circ} \mathrm{C} \\
\text { Soil moisture contents: } 15 \%, 40 \%, 60 \% \text {, and } 90 \% \\
\text { pH values: } 6.0,7.0 \text {, and } 8.0 \\
\text { Sampling times up to } 150 \text { days } \\
\text { Analytical determination: } \mathrm{HPLC} / \mathrm{MS} / \mathrm{MS}\end{array}$ & $\begin{array}{l}\text { Imazapic degradation rate increased } \\
\text { with temperature, soil } \mathrm{pH} \text {, and soil } \\
\text { moisture, and it decreased with } \mathrm{OM} \\
\text { content. Biogas slurry accelerated } \\
\text { imazapic degradation (significant } \\
\text { microbial contribution to its } \\
\text { degradation). }\end{array}$ & Su et al. [159] \\
\hline $\begin{array}{l}\text { Chlorotoluron } \\
\text { Flufenacet }\end{array}$ & $\begin{array}{c}\text { Sandy loam soil } \\
\text { (pH 6.34, OC } 0.77 \text {, clay } \\
14.9 \% \text {, silt } 4.7 \% \text { ) }\end{array}$ & $\begin{array}{c}\text { Spent mushroom substrate (SMS) } \\
\text { (pH 7.9, OM 59.4\%, DOM 0.8\%) } \\
\text { Green compost (GC) (pH 7.2, OM } \\
46.0 \%, \text { DOM } 0.7 \%) \\
\text { SMS and GC/soil: } 140 \text { and } \\
85 \mathrm{t} \mathrm{ha}^{-1}\end{array}$ & $\begin{array}{c}\text { Soil samples: } 600 \mathrm{~g} \\
\text { Pesticide applied: } 14 \mathrm{mg} \text { (chlorotoluron) and } \\
5.5 \mathrm{mg} \text { (flufenacet) } / \mathrm{kg} \text { of dry soil } \\
\text { Soil moisture content: } 40 \% \mathrm{WHC} \\
\text { Incubation T: } 6 \text { and } 16^{\circ} \mathrm{C} \\
\text { Sampling times up to } 67 \text { or } 273 \text { days } \\
\text { Analytical determination: HPLC/MS }\end{array}$ & $\begin{array}{l}\text { Flufenacet degradation was slower } \\
\text { than that of chlorotoluron. } \\
\text { Amendments increased } \mathrm{DT}_{50} \text { values } \\
\text { for both herbicides incubated at both } \\
\text { temperatures, especially at } 16^{\circ} \mathrm{C} \text { due } \\
\text { to the higher microbiological activity. }\end{array}$ & $\begin{array}{c}\text { Marín-Benito } \\
\text { et al. [160] }\end{array}$ \\
\hline
\end{tabular}


Table 3. Cont.

\begin{tabular}{|c|c|c|c|c|c|}
\hline Pesticide & $\begin{array}{c}\text { Soil } \\
\text { Characteristics }\end{array}$ & Organic Amendment/Dose & Experimental Design & Results & Reference \\
\hline $\begin{array}{c}{ }^{14} \mathrm{C}- \\
\text { Prosulfocarb }\end{array}$ & $\begin{array}{l}\text { Sandy clay loam soil } \\
\text { (pH 7.35, OC 1.30, clay } \\
\text { 17\%, silt } 25 \%)\end{array}$ & $\begin{array}{c}\text { Green compost (GC) (pH 7.20, OC } \\
24.1 \% \text {, DOM 0.703\%) } \\
\text { GC/soil: } 20 \% \mathrm{w} \mathrm{w}^{-1}\left(180 \mathrm{tha}^{-1}\right)\end{array}$ & $\begin{array}{c}\text { Soil samples: } 500-700 \mathrm{~g} \\
\text { Pesticide applied: } 4 \text { and } 10 \mathrm{mg} \mathrm{kg}^{-1} \text { of dry soil } \\
\text { and } 100 \mathrm{~Bq} \mathrm{~g} \mathrm{~g}^{-1} \\
\text { Soil moisture content: } 40 \% \mathrm{WHC} \\
\text { Incubation } \mathrm{T}: 20^{\circ} \mathrm{C} \\
\text { Sampling times up to } 50 \text { days } \\
\text { Analytical determination: HPLC/MS and } \\
\text { Liquid scintillation }\end{array}$ & $\begin{array}{l}\text { Highest } \mathrm{DT}_{50} \text { values in amended soil. } \\
\text { They increased with the herbicide } \\
\text { concentration in unamended soil but } \\
\text { decreased in amended soil. Lost } \\
\text { through volatilization of herbicide was } \\
\text { consistent with the total }{ }^{14} \mathrm{C} \text { mass } \\
\text { balance close to } 70 \% \text { at the end of } \\
\text { dissipation period. }\end{array}$ & Barba et al. [161] \\
\hline $\begin{array}{l}\text { Mesotrione } \\
\text { Pethoxamid } \\
\text { Triasulfuron }\end{array}$ & $\begin{array}{c}\text { Sandy loam soil } \\
(\mathrm{pH} 6.3, \text { OC } 0.49 \% \\
\text { clay } 10.7 \% \text {, silt } 5.9 \%)\end{array}$ & $\begin{array}{c}\text { Sewage sludge (SS) (pH 7.08, OC } \\
\text { 8.06\%, DOM } 0.102 \%) \\
\text { Green compost (GC) }(\mathrm{pH} 6.73, \mathrm{OC} \\
27.0 \%, \text { DOM } 2.17 \%) \\
\text { SS or GC/soil: } 50 \mathrm{t} \mathrm{ha}^{-1}\end{array}$ & $\begin{array}{c}\text { Soil samples: } 800 \mathrm{~g} \\
\text { Pesticide applied: } 2 \mathrm{mg} \mathrm{kg}^{-1} \text { of dry soil } \\
\text { Soil moisture content: } 40 \% \text { WHC } \\
\text { Incubation T: } 20{ }^{\circ} \mathrm{C} \\
\text { Sampling times up to } 99,43 \text { and } 144 \text { days } \\
\text { Analytical determination: HPLC/MS }\end{array}$ & $\begin{array}{l}\text { Repeated application of pesticides } \\
\text { decreased (mesotrione) or increased } \\
\text { (petoxamide) its dissipation rate in all } \\
\text { treatments. For triasulfuron, it } \\
\text { increased only in amended soils. } \\
\text { Highest DT } \text { D }_{50} \text { values for pethoxamid } \\
\text { and triasulfuron in } \mathrm{S}+\mathrm{GC} \text {, and for } \\
\text { mesotriona in } \mathrm{S}+\mathrm{SS} \text {. }\end{array}$ & Pose et al. [167] \\
\hline
\end{tabular}


Author Contributions: Conceptualization, M.J.C., M.J.S.-M., M.S.R.-C. and J.M.M.-B.; writingoriginal draft preparation, M.J.C., M.J.S.-M. and J.M.M.-B.; writing-review and editing, M.J.S.-M., M.S.R.-C. and J.M.M.-B.; supervision, M.J.S.-M., M.S.R.-C. and J.M.M.-B.; project administration, J.M.M.-B.; funding acquisition, J.M.M.-B. All authors have read and agreed to the published version of the manuscript.

Funding: This research was funded by MCIU/AEI/FEDER UE, Project "RTI2018-101587-J-I00". M.J. Carpio thanks for her predoctoral contract co-funded by European Social Fund (ESF) and the Consejería de Educación (Junta de Castilla y León Government).

Institutional Review Board Statement: Not applicable.

Informed Consent Statement: Not applicable.

Acknowledgments: Project “CLU-2019-05-IRNASA/CSIC Unit of Excellence”, funded by the Junta de Castilla y León and co-financed by the European Union (ERDF “Europe drives our growth").

Conflicts of Interest: The authors declare no conflict of interest.

\section{References}

1. Imfeld, G.; Vuilleumier, S. Measuring the effects of pesticides on bacterial communities in soil: A critical review. Eur. J. Soil Biol. 2012, 49, 22-30. [CrossRef]

2. Nyamwasa, I.; Li, K.; Rutikanga, A.; Rukazambuga, D.N.T.; Zhang, S.; Yin, J.; Ya-Zhong, C.; Zhang, X.X.; Sun, X. Soil insect crop pests and their integrated management in East Africa: A review. Crop Prot. 2018, 106, 163-176. [CrossRef]

3. United Nations. Global Issues. Our Global Population. 2020. Available online: https://www.un.org/en/sections/issues-depth/ population (accessed on 10 September 2020).

4. Ahmad, A.; Shahid, M.; Khalid, S.; Zaffar, H.; Naqvi, T.; Pervez, A.; Bilal, M.; Ali, M.A.; Abbas, G.; Nasim, W. Residues of endosulfan in cotton growing area of Vehari, Pakistan: An assessment of knowledge and awareness of pesticide use and health risks. Environ. Sci. Pollut. 2018, 26, 20079-20091. [CrossRef] [PubMed]

5. Sharma, A.; Kumar, V.; Shahzad, B.; Tanveer, M.; Preet, G.; Sidhu, S.; Handa, N. Worldwide pesticide usage and its impacts on ecosystem. SN Appl. Sci. 2019, 1, 1-16. [CrossRef]

6. Pesticide Reports. Pesticides Global Market Opportunities and Strategies to 2023. 2020. Available online: https://www. thebusinessresearchcompany.com/report/pesticides-market (accessed on 10 September 2020).

7. Worldatlas. 2018. Available online: https://www.worldatlas.com/articles/top--pesticideconsuming--countries--of--the--world. html (accessed on 10 September 2020).

8. Hvězdová, M.; Kosubová, P.; Košíková, M.; Scherr, K.E.; Šimek, Z.; Brodský, L.; Šudoma, M.; Škulcová, L.; Sáňka, M.; Svobodová, M.; et al. Currently and recently used pesticides in Central European arable soils. Sci. Total Environ. 2018, 613-614, 361-370. [CrossRef]

9. Silva, V.; Mol, H.G.J.; Zomer, P.; Tienstra, M.; Ritsema, C.J.; Geissen, V. Pesticide residues in European agricultural soils-A hidden reality. Sci. Total Environ. 2019, 653, 1532-1545. [CrossRef]

10. Picó, Y.; Alvarez-Ruiz, R.; Alfarhan, A.H.; El-Sheikh, M.A.; Alshahrani, H.O.; Barceló, D. Pharmaceuticals, pesticides, personal care products and microplastics contamination assessment of Al-Hassa irrigation network (Saudi Arabia) and its shallow lakes. Sci. Total Environ. 2020, 701, 135021. [CrossRef] [PubMed]

11. Vangronsveld, J.; Herzig, R.; Weyens, N.; Boulet, J.; Adriaensen, K.; Ruttens, A.; Thewys, T.; Vassilev, A.; Meers, E.; Nehnevajova, E.; et al. Phytoremediation of contaminated soils and groundwater: Lessons from the field. Environ. Sci. Pollut. 2009, 16, 765-794. [CrossRef] [PubMed]

12. Sánchez-González, S.; Pose-Juan, E.; Herrero-Hernández, E.; Álvarez-Martín, A.; Sánchez-Martín, M.J.; Rodríguez-Cruz, S. Pesticide residues in groundwaters and soils of agricultural areas in the Águeda River Basin from Spain and Portugal. Int. J. Environ. Anal. Chem. 2013, 93, 1585-1601. [CrossRef]

13. Pose-Juan, E.; Sánchez-Martín, M.J.; Andrades, M.S.; Rodríguez-Cruz, M.S.; Herrero-Hernández, E. Pesticide residues in vineyard soils from Spain: Spatial and temporal distributions. Sci. Total Environ. 2015, 514, 351-358. [CrossRef]

14. Herrero-Hernández, E.; Pose-Juan, E.; Sánchez-Martín, M.J.; Andrades, M.S.; Rodríguez-Cruz, M.S. Intra-annual trends of fungicide residues in waters from vineyard areas in La Rioja region of northern Spain. Environ. Sci. Pollut. Res. 2016, 23, 22924-22936. [CrossRef] [PubMed]

15. AL-Ahmadi, M.S. Pesticides, anthropogenic activities, and the health of our environment safety. IntechOpen 2019. [CrossRef]

16. Baxter, J.; Cummings, S.P. The degradation of the herbicide bromoxynil and its impact on bacterial diversity in a top soil. J. Appl. Microbiol. 2008, 104, 1605-1616. [CrossRef]

17. Arora, S.; Sahni, D.; Sehgal, M.; Srivastava, D.; Singh, A. Pesticides use and its effect on soil bacteria and fungal populations; microbial biomass carbon and enzymatic activity. Curr. Sci. 2019, 116, 643-649. [CrossRef]

18. Satapute, P.; Kamble, M.V.; Adhikari, S.S.; Jogaiah, S. Influence of triazole pesticides on tillage soil microbial populations and metabolic changes. Sci. Total Environ. 2019, 651, 2334-2344. [CrossRef] 
19. Zhang, Q.; Saleem, M.; Wang, C. Effects of biochar on the earthworm (Eisenia foetida) in soil contaminated with and/or without pesticide mesotrione. Sci. Total Environ. 2019, 671, 52-58. [CrossRef]

20. Li, Y.; Niu, J.; Shen, Z.; Zhang, C.; Wang, Z.; He, T. Spatial and seasonal distribution of organochlorine pesticides in the sediments of the Yangtze Estuary. Chemosphere 2014, 114, 233-240. [CrossRef]

21. Herrero-Hernández, E.; Rodríguez-Cruz, M.S.; Pose-Juan, E.; Sánchez-González, S.; Andrades, M.S.; Sánchez-Martín, M.J. Seasonal distribution of herbicide and insecticide residues in the water resources of the vineyard region of La Rioja (Spain). Sci. Total Environ. 2017, 609, 161-171. [CrossRef]

22. Sousa, J.C.G.; Ribeiro, A.R.; Barbosa, M.O.; Pereira, M.F.R.; Silva, A.M.T. A review on environmental monitoring of water organic pollutants identified by EU guidelines. J. Hazard. Mater. 2018, 344, 146-162. [CrossRef] [PubMed]

23. Barizon, R.R.M.; Figueiredo, R.O.; de Souza Dutra, D.R.C.; Regitano, J.B.; Ferracini, V.L. Pesticides in the surface waters of the Camanducaia River watershed, Brazil. J. Environ. Sci. Health B 2020, 55, 283-292. [CrossRef]

24. Kapsi, M.; Tsoutsi, C.; Paschalidou, A.; Albanis, T. Environmental monitoring and risk assessment of pesticide residues in surface waters of the Louros River (N.W. Greece). Sci. Total Environ. 2019, 650, 2188-2198. [CrossRef]

25. Herrero-Hernández, E.; Simón-Egea, A.B.; Sánchez-Martín, M.J.; Rodríguez-Cruz, M.S.; Andrades, M.S. Monitoring and environmental risk assessment of pesticide residues and some of their degradation products in natural waters of the Spanish vineyard region included in the Denomination of Origin Jumilla. Environ. Pollut. 2020, 264, 114666. [CrossRef]

26. Marsala, R.Z.; Capri, E.; Russo, E.; Bisagni, M.; Colla, R.; Lucini, L.; Gallo, A.; Suciu, N.A. First evaluation of pesticides occurrence in groundwater of Tidone Valley, an area with intensive viticulture. Sci. Total Environ. 2020, 736, 139730. [CrossRef] [PubMed]

27. Directive 2008/105/EC of the European Parliament and of the Council of 16 December 2008 on environmental quality standards in the field of water policy, amending and subsequently repealing Council Directives 82/176/EEC, 83/513/EEC, 84/156/EEC, 84/491/EEC, 86/280/EEC and amending Directive 2000/60/EC of the European Parliament and of the Council. Off. J. Eur. Union L 2008, 348, 84-97.

28. Marín-Benito, J.M.; Sánchez-Martín, M.J.; Rodríguez-Cruz, M.S. Impact of spent mushroom substrates on the fate of pesticides in soil, and their use for preventing and/or controlling soil and water contamination: A review. Toxics 2016, 4, 17. [CrossRef]

29. Álvarez-Martín, A.; Rodríguez-Cruz, M.S.; Andrades, M.S.; Sánchez-Martín, M.J. Application of a biosorbent to soil: A potential method for controlling water pollution by pesticides. Environ. Sci. Pollut. Res. 2016, 23, 9192-9203. [CrossRef]

30. Khorram, M.S.; Zhang, Q.; Lin, D.; Zheng, Y.; Fang, H.; Yu, Y. Biochar: A review of its impact on pesticide behavior in soil environments and its potential applications. J. Environ. Sci. 2016, 44, 269-279. [CrossRef] [PubMed]

31. Barrow, C.J. Biochar: Potential for countering land degradation and for improving agriculture. Appl. Geogr. 2012, 34, 21-28. [CrossRef]

32. Dickerson, G. A Sustainable Approach to Recycling Urban and Agricultural Organic Wastes; Guide H-159, Cooperative Extension Service; College of Agriculture and Home Economics: Belen, NM, USA, 2000.

33. Moral, R.; Moreno-Caselles, J.; Perez-Murcia, M.; Perez-Espinosa, A.; Rufete, B.; Paredes, C. Characterization of the organic matter pool in manures. Bioresour. Technol. 2005, 96, 153-158. [CrossRef] [PubMed]

34. Marín-Benito, J.M.; Andrades, M.S.; Rodríguez-Cruz, M.S.; Sánchez-Martín, M.J. Changes in the sorption-desorption of fungicides over time in an amended sandy clay loam soil under laboratory conditions. J. Soils Sediments 2012, 12, 1111-1123. [CrossRef]

35. Rodríguez-Cruz, M.S.; Herrero-Hernández, E.; Ordax, J.M.; Marín-Benito, J.M.; Draoui, K.; Sánchez-Martín, M.J. Adsorption of pesticides by sewage sludge, grape marc, spent mushroom substrate and by amended soils. Int. J. Environ. Anal. Chem. 2012, 92, 933-948. [CrossRef]

36. Castillo, J.M.; Beguet, J.; Martin-Laurent, F.; Romero, E. Multidisciplinary assessment of pesticide mitigation in soil amended with vermicomposted agroindustrial wastes. J. Hazard. Mater. 2016, 304, 379-387. [CrossRef] [PubMed]

37. Worrall, F.; Fernandez-Perez, M.; Johnson, A.C.; Flores-Cesperedes, F.; Gonzalez-Pradas, E. Limitations on the role of incorporated organic matter in reducing pesticide leaching. J. Contam. Hydrol. 2001, 49, 241-262. [CrossRef]

38. Goss, M.J.; Tubeileh, A.; Goorahoo, D. A review of the use of organic amendments and the risk to human health. Adv. Agron. 2013, 120, 275-379.

39. Scotti, R.; Bonanomi, G.; Scelza, R.; Zoina, A.; Rao, M.A. Organic amendments as sustainable tool to recovery fertility in intensive agricultural systems. J. Plant. Nutr. Soil Sci. 2015, 15, 333-352. [CrossRef]

40. Medina, E.; Paredes, C.; Bustamante, M.A.; Moral, R.; Moreno-Caselles, J. Relationships between soil physico-chemical, chemical and biological properties in a soil amended with spent mushroom substrate. Geoderma 2012, 173-174, 152-161. [CrossRef]

41. Lugato, E.; Bampa, F.; Panagos, P.; Montanarella, L.; Jones, A. Potential carbon sequestration of European arable soils estimated by modelling a comprehensive set of management practices. Glob. Change Biol. 2014, 20, 3557-3567. [CrossRef]

42. Hijbeek, R.; Van Ittersum, M.K.; ten Berge, H.F.; Gort, G.; Spiegel, H.; Whitmore, A.P. Do organic inputs matter-A meta-analysis of additional yield effects for arable crops in Europe. Plant Soil 2017, 411, 293-303. [CrossRef]

43. UNFCCC, United Nations Framework Convention on Climate Change. Join the 4/1000 Initiative. In Soils for Food Security and Climate; UNFCCC: Rio de Janeiro, Brazil; New York, NY, USA, 2015; Available online: https:/ / unfccc.int/news/join--the--41000-initiative--soils--for--food--security--and--climate (accessed on 10 September 2020).

44. Donn, S.; Wheatley, R.E.; McKenzie, B.M.; Loades, K.W.; Hallett, P.D. Improved soil fertility from compost amendment increases root growth and reinforcement of surface soil on slope. Ecol. Eng. 2014, 71, 458-465. [CrossRef] 
45. Singh, R.P.; Singh, P.; Ibrahim, M.H.; Hashim, R. Land Application of sewage sludge: Physicochemical and microbial response. Rev. Environ. Contam. Toxicol. 2011, 214, 41-61.

46. Gómez-Sagasti, M.T.; Hernández, A.; Artetxe, U.; Garbisu, C.; Becerril, J.M. How Valuable Are Organic Amendments as Tools for the Phytomanagement of Degraded Soils? The Knowns, Known Unknowns, and Unknowns. Front. Sustain. Food Syst. 2018, 2, 68. [CrossRef]

47. Fließbach, A.; Oberholzer, H.R.; Gunst, L.; Mäder, P. Soil organic matter and biological soil quality indicators after 21 years of organic and conventional farming. Agric. Ecosyst. Environ. 2007, 118, 273-284. [CrossRef]

48. Montiel-Rozas, M.M.; Domínguez, M.T.; Madejón, E.; Madejón, P.; Pastorelli, R.; Renella, G. Long-term effects of organic amendments on bacterial and fungal communities in a degraded Mediterranean soil. Geoderma 2018, 332, 20-28. [CrossRef]

49. Urra, J.; Alkorta, I.; Garbisu, C. Potential benefits and risks for soil health derived from the use of organic amendments in agriculture. Agronomy 2019, 9, 542. [CrossRef]

50. Li, R.; Khafipour, E.; Krause, D.O.; Entz, M.H.; de Kievit, T.R.; Fernando, W.D. Pyrosequencing reveals the influence of organic and conventional farming systems on bacterial communities. PLoS ONE 2012, 7, 51897. [CrossRef] [PubMed]

51. Memoli, V.; De Marco, A.; Baldantoni, D.; De Nicola, F.; Maisto, G. Short- and long-term effects of a single application of two organic amendments. Ecosphere 2017, 8, e02009. [CrossRef]

52. Ventorino, V.; de Marco, A.; Pepe, O.; Virzo de Santo, A.; Moschetti, G. Impact of Innovative Agricultural Practices of Carbon Sequestration on Soil Microbial Community. Carbon Sequestration in Agricultural Soils. A Multidisciplinary Approach to Innovative Methods; Piccolo, A., Ed.; Springer: Berlin/Heidelberg, Germany, 2012; pp. 145-177. [CrossRef]

53. Abbott, L.K.; Macdonald, L.M.; Wong, M.T.F.; Webb, M.J.; Jenkins, S.N.; Farrell, M. Potential roles of biological amendments for profitable grain production-A review. Agric. Ecosyst. Environ. 2018, 256, 34-50. [CrossRef]

54. Edmeades, D.C. The long-term effects of manures and fertilizers on soil productivity and quality: A review. Nut. Cycl. Agroecosyst. 2003, 66, 165-180. [CrossRef]

55. Leroy, B.L.M.; Herath, H.M.S.K.; Sleutel, S.; De Neve, S.; Gabriels, D.; Reheul, D.; Moens, M. The quality of exogenous organic matter: Short-term effects on soil physical properties and soil organic matter fractions. Soil Use Manag. 2008, 24, 139-147. [CrossRef]

56. Scotti, R.; Conte, P.; Berns, A.E.; Alonzo, G.; Rao, M.A. Effect of organic amendments on the evolution of soil organic matter in soils stressed by intensive agricultural practices. Curr. Org. Chem. 2013, 17, 2998-3005. [CrossRef]

57. Six, J.; Paustian, K. Aggregate-associated soil organic matter as an ecosystem property and a measurement tool. Soil Biol. Biochem. 2014, 68, A4-A9. [CrossRef]

58. Ingelmo-Sánchez, F.; Rubio-Delgado, J. Efecto de la aplicación del compost sobre las propiedades físicas y químicas del suelo. In Compostaje; Moreno-Casco, J., Moral-Herrero, R., Eds.; Mundi-Prensa: Madrid, Spain, 2008.

59. Hernández, T.; García, E.; García, C. A strategy for marginal semiarid degraded soil restoration: A sole addition of compost at a high rate. A five-year field experiment. Soil Biol. Biochem. 2015, 89, 61-71. [CrossRef]

60. Zhang, H.; Luo, Y.; Wu, L.; Huang, Y.; Christie, P. Residues and potential ecological risks of veterinary antibiotics in manures and composts associated with protected vegetable farming. Environ. Sci. Pollut. Res. Int. 2015, 22, 5908-5918. [CrossRef]

61. Pan, M.; Chu, L.M. Leaching behavior of veterinary antibiotics in animal manure-applied soils. Sci. Total Environ. 2017, 579, 466-473. [CrossRef] [PubMed]

62. Godlewska, P.; Ok, Y.S.; Oleszczuk, P. The dark side of black gold: Ecotoxicological aspects of biochar and biochar-amended soils. J. Hazard. Mater. 2021, 403, 123833. [CrossRef] [PubMed]

63. Tao, R.; Li, J.; Hu, B.; Chu, G. Ammonia-oxidizing bacteria are sensitive and not resilient to organic amendment and nitrapyrin disturbances, but ammonia-oxidizing archaea are resistant. Geoderma 2021, 384, 114814. [CrossRef]

64. EUROSTAT, Statistical Office of the European Communities. Waste Statistics. 2020. Available online: https://ec.europa.eu/ eurostat/statistics--explained/index.php/Waste_statistics (accessed on 10 September 2020).

65. EC, European Commission Decision 2015/2099. Review of Waste Policy and Legislation. 2020. Available online: https: / / ec.europa.eu/environment/waste/target_review.htm (accessed on 10 September 2020).

66. ECN, European Compost Network. Bio-Waste in Europe. 2020. Available online: https://www.compostnetwork.info/policy/ biowaste--in--europe/ (accessed on 10 September 2020).

67. EEA, European Environment Agency. Waste Generation in Europe. 2020. Available online: https://www.eea.europa.eu/data-and--maps/indicators/waste--generation--4/assessment\#: \{\}:text=More\%20and $\% 20 \mathrm{more} \% 20 \mathrm{waste} \% 20 \mathrm{is}, \mathrm{by} \% 2070 \% 20 \mathrm{~kg} \%$ 20per\%20capita (accessed on 10 September 2020).

68. Vimal, S.R.; Singh, J.S.; Arora, N.K.; Singh, S. Soil-plant-microbe interactions in stressed agriculture management: A review. Pedosphere 2017, 27, 177-192. [CrossRef]

69. EC (European Commission). Impact Assessment of the Thematic Strategy on Soil SEC 620. 2006. Available online: https: / / ec.europa.eu/environment/archives/soil/pdf/SEC_2006_620.pdf (accessed on 10 September 2020).

70. Martínez-Blanco, J.; Lazcano, C.; Christensen, T.H.; Muñoz, P.; Rieradevall, J.; Møller, J.; Antón, A.; Boldrin, A. Compost benefits for agriculture evaluated by life cycle assessment. A review. Agron. Sustain. Dev. 2013, 33, 721-732. [CrossRef]

71. Schreuder, R.; De Visser, C. EIP AGRI Focus Group Protein Crops: Final Report. European Innovation Partnership for Agricultural Productivity and Sustainability (EIP AGRI). Brussels. 2014. Available online: https://ec.europa.eu/eip/agriculture/en/ publications / eip-agri-focus-group-protein-crops-final-report (accessed on 10 September 2020). 
72. Saveyn, H.; Eder, P. End of Waste Criteria for Biodegradable Waste Subjected to Biological Treatment (Compost and Digestate): Technical Proposal; @ European Commission in 2014, EUR 26425; Joint Research Centre-Institute for Prospective Technological Studies: Luxembourg, 2014; p. 310.

73. Büyüksönmez, F.; Rink, R.; Hess, T.; Bechinski, E. Occurrence, degradation and fate of pesticides during composting. Part I. Composting, pesticides, and pesticides degradation. Compost Sci. Util. 1999, 7, 66-82. [CrossRef]

74. Büyüksönmez, F.; Rynk, R.; Hess, T.; Bechinski, E. Occurrence, degradation and fate of pesticides during composting. Part II. Occurrence and fate de pesticides in compost and composting systems. Compost Sci. Util. 2000, 8, 61-81. [CrossRef]

75. Briceño, G.; Palma, G.; Durán, N. Influence of organic amendment on the biodegradation and movement of pesticides. Crit. Rev. Environ. Sci. Technol. 2007, 37, 233-271. [CrossRef]

76. Marín-Benito, J.M.; Rodríguez-Cruz, M.S.; Andrades, M.S.; Sánchez-Martín, M.J. Assessment of spent mushroom substrate as sorbent of fungicides: Influence of sorbent and sorbate properties. J. Environ. Qual. 2012, 41, 814-822. [CrossRef] [PubMed]

77. Marín-Benito, J.M.; Andrades, M.S.; Sánchez-Martín, M.J.; Rodríguez-Cruz, M.S. Dissipation of fungicides in a vineyard soil amended with different spent mushroom substrates. J. Agric. Food Chem. 2012, 60, 6936-6945. [CrossRef] [PubMed]

78. Marín-Benito, J.M.; Brown, C.D.; Herrero-Hernández, E.; Arienzo, M.; Sánchez-Martín, M.J.; Rodríguez-Cruz, M.S. Use of raw or incubated organic wastes as amendments in reducing pesticide leaching through soil columns. Sci. Total Environ. 2013, 463-464, 589-599. [CrossRef] [PubMed]

79. Marín-Benito, J.M.; Herrero-Hernández, E.; Andrades, M.S.; Sánchez-Martín, M.J.; Rodríguez-Cruz, M. Effect of different organic amendments on the dissipation of linuron, diazinon and myclobutanil in an agricultural soil incubated for different time periods. Sci. Total Environ. 2014, 476-477, 611-621. [CrossRef] [PubMed]

80. Zolgharnein, J.; Shahmoradi, A.; Ghasemi, J. Pesticides removal using conventional and low-cost adsorbents: A review. Clean-Soil Air Water 2011, 39, 1105-1119. [CrossRef]

81. Garrido, I.; Vela, N.; Fenoll, J.; Navarro, G.; Pérez-Lucas, G.; Navarro, S. Testing of leachability and persistence of sixteen pesticides in three agricultural soils of a semiarid Mediterranean region. Span. J. Agric. Res. 2015, 13, 1104. [CrossRef]

82. Zhang, G.; Liu, X.; Sun, K.; Zhao, Y.; Lin, C. Sorption of Tetracycline to Sediments and Soils: Assessing the roles of pH, the presence of cadmium and properties of sediments and soils. FESE 2010, 4, 421-429. [CrossRef]

83. Gavrilescu, M. Fate of pesticides in the environment and its bioremediation. Eng. Life Sci. 2005, 5, 497-525. [CrossRef]

84. Jiang, L.; Lin, J.L.; Jia, L.X.; Liu, Y.; Pan, B.; Yang, Y.; Lin, Y. Effects of two different organic amendments addition to soil on sorption-desorption, leaching, bioavailability of penconazole and the growth of wheat (Triticum. aestivum L.). J. Environ. Manag. 2016, 167, 130-138. [CrossRef]

85. Loffredo, E.; Parlavecchia, M.; Perri, G.; Gattullo, R. Comparative assessment of metribuzin sorption efficiency of biochar, hydrochar and vermicompost. J. Environ. Sci. Health B 2019, 54, 728-735. [CrossRef]

86. Petter, F.A.; Ferreira, T.S.; Sinhorin, A.P.; Lima, L.B.; Almeida, F.A.; Pacheco, L.P.; Silva, A.F. Biochar increases diuron sorption and reduces the potential contamination of subsurface water with diuron in a sandy soil. Pedosphere 2019, 29, 801-809. [CrossRef]

87. García-Jaramillo, M.; Trippe, K.M.; Helmus, R.; Knicker, H.E.; Cox, L.; Hermosín, M.C.; Kalbitz, K. An examination of the role of biochar and biochar water-extractable substances on the sorption of ionizable herbicides in rice paddy soils. Sci. Total Environ. 2020, 706, 135682. [CrossRef]

88. Khan, S.U. Pesticides in the Soil Environment; Elsevier: New, York, NY, USA, 2016.

89. Wu, C.; Liu, X.; Wu, X.; Dong, F.; Xu, J.; Zheng, Y. Sorption, degradation and bioavailability of oxyfluorfen in biochar-amended soils. Sci. Total Environ. 2019, 658, 87-94. [CrossRef]

90. Cox, L.; Cecchi, A.; Celis, R.; Hermosín, M.; Koskinen, W.; Cornejo, J. Effect of exogenous carbon on movement of simazine and 2,4-D in soils. Soil Sci. Soc. Am. J. 2001, 65, 1688-1695. [CrossRef]

91. Plaza, C.; Polo, A.; Brunetti, G.; Garcia-Gil, J.; D'Orazio, V. Soil fulvic acid properties as a means to assess the use of pig amendment. Soil Till. Res. 2003, 74, 179-190. [CrossRef]

92. Thorstensen, C.; Lode, O.; Eklo, O.; Christianse, A. Sorption of bentazone, dichlorprop, MCPA, and propiconazole in references soils from Norway. J. Environ. Qual. 2001, 30, 2046-2052. [CrossRef]

93. Cambier, P.; Pot, V.; Mercier, V.; Michaud, A.; Benoit, P.; Revallier, A.; Houot, S. Impact of long-term organic residue recycling in agriculture on soil solution composition and trace metal leaching in soils. Sci. Total Environ. 2014, 499, 560-573. [CrossRef]

94. Barriuso, E.; Andrades, M.S.; Benoit, P.; Houot, S. Pesticide desorption from soils facilitated by dissolved organic matter coming from composts: Experimental data and modelling approach. Biogeochemistry 2011, 106, 117-133. [CrossRef]

95. Huang, X.; Lee, S. Effects of dissolved organic matter from animal waste effluent on chlorpyrifos sorption by soils. J. Environ. Qual. 2001, 30, 1258-1265. [CrossRef]

96. Álvarez-Martín, A.; Sánchez-Martín, M.J.; Ordax, J.M.; Marín-Benito, J.M.; Rodríguez-Cruz, M.S. Leaching of two fungicides in spent mushroom substrate amended soil: Influence of amendment rate; fungicide ageing and flow condition. Sci. Total Environ. 2017, 584-585, 828-837. [CrossRef]

97. Rodríguez-Liébana, J.A.; Peña, A. Adsorption-desorption of dimethenamid and fenarimol onto three agricultural soils as affected by treated wastewater and fresh sewage sludge-derived dissolved organic carbon. J. Environ. Manag. 2018, 217, 592-599. [CrossRef]

98. Wanner, U.; Führ, F.; Burauel, P. Influence of the amendment of corn straw on the degradation behaviour of the fungicide dithianon in soil. Environ. Pollut. 2005, 133, 63-70. [CrossRef] 
99. Wang, H.; Lin, K.; Hou, Z.; Richardson, B.; Gan, J. Sorption of the herbicide terbuthylazine in two New Zealand forest soils amended with biosolids and biochars. J. Soils Sediments 2010, 10, 283-289. [CrossRef]

100. Thevenot, M.; Dousset, S. Compost effect on diuron retention and transport in structured vineyard soils. Pedosphere 2015, 25, 25-36. [CrossRef]

101. Li, K.; Xing, B.S.; William, A.T. Effect of organic fertilizers derived dissolved organic matter on they sorption and leaching. Environ. Pollut. 2005, 134, 187-194. [CrossRef] [PubMed]

102. Spark, K.M.; Swift, R.S. Effect of soil composition and dissolved organic matter on pesticide sorption. Sci. Total Environ. 2002, 298, 147-161. [CrossRef]

103. Parlavecchia, M.; Orazio, V.D.; Loffredo, E. Wood biochars and vermicomposts from digestate modulate the extent of adsorptiondesorption of the fungicide metalaxyl-m in a silty soil. Environ. Sci. Pollut. Res. Int. 2019, 26, 35924-35934. [CrossRef] [PubMed]

104. Deng, H.; Feng, D.; He, J.; Li, F.; Yu, H.; Ge, C. Influence of biochar amendments to soil on the mobility of atrazine using sorption-desorption and soil thin-layer chromatography. Ecol. Eng. 2017, 99, 381-390. [CrossRef]

105. Mendes, K.F.; de Sousa, R.N.; Takeshita, V.; Alonso, F.G.; Régo, A.P.J.; Tornisielo, V.L. Cow bone char as a sorbent to increase sorption and decrease mobility of hexazinone, metribuzin, and quinclorac in soil. Geoderma 2019, 343, 40-49. [CrossRef]

106. Mendes, K.F.; Hall, K.E.; Takeshita, V.; Rossi, M.L.; Tornisielo, V.L. Animal bonechar increases sorption and decreases leaching potential of aminocyclopyrachlor and mesotrione in a tropical soil. Geoderma 2018, 316, 11-18. [CrossRef]

107. Marín-Benito, J.M.; Herrero-Hernández, E.; Rodríguez-Cruz, M.S.; Arienzo, M.; Sánchez-Martín, M.J. Study of processes influencing bioavailability of pesticides in wood-soil systems: Effect of different factors. Ecotoxicol. Environ. Saf. 2017, 139, 454-462. [CrossRef]

108. Mendes, K.F.; Alonso, F.G.; Mertens, T.B.; Inoue, M.; Oliveira, M.G.D.; Tornisielo, V.L. Aminocyclopyrachlor and mesotrione sorption-desorption in municipal sewage sludge-amended soil. Soil Plant Nutr. 2019, 78, 131-140. [CrossRef]

109. Duhan, A.; Oliver, D.P.; Rashti, M.R.; Du, J.; Kookana, R.S. Organic waste from sugar mills as a potential soil ameliorant to minimize herbicide runoff to the Great Barrier Reef. Sci. Total Environ. 2020, 713, 136640. [CrossRef]

110. Di Marsico, A.; Scrano, L.; Amato, M.; Gàmiz, B.; Real, M.; Cox, L. Mucilage from seeds of chia (Salvia hispanica L.) used as soil conditioner, effects on the sorption-desorption of four herbicides in three different soils. Sci. Total Environ. 2018, 625, 531-538. [CrossRef]

111. Xing, B. Sorption of naphthalene and phenanthrene by soil humic acids. Environ. Pollut. 2001, 111, 303-309. [CrossRef]

112. Gaonkar, O.D.; Nambi, I.M.; Govindarajan, S.K. Soil organic amendments: Impacts on sorption of organophosphate pesticides on an alluvial soil. J. Soils Sediments 2019, 19, 566-578. [CrossRef]

113. Wang, T.; Zhang, Z.; Zhang, H.; Zhong, X.; Liu, Y.; Liao, S.; Yuea, X.; Zhouc, G. Sorption of carbendazim on activated carbons derived from rape straw and its mechanism. RSC Adv. 2019, 9, 41745-41754. [CrossRef]

114. García-Delgado, C.; Marín-Benito, J.M.; Sánchez-Martín, M.J.; Rodríguez-Cruz, M.S. Organic carbon nature determines the capacity of organic amendments to adsorb pesticides in soil. J. Hazard. Mater. 2020, 390, 122162. [CrossRef]

115. Bear, J.; Cheng, A.H.D. Modeling Groundwater Flow and Contaminant Transport; Springer: Dordrecht, The Netherlands, 2010.

116. Carter, A. Herbicide movement in soils: Principles, pathways and processes. Weed Res. 2000, 40, 113-122. [CrossRef]

117. Navarro, S.; Vela, N.; Navarro, G. An overview on the environmental behavior of pesticide residues in soils. Span. J. Agric. Res. 2007, 5, 357-375. [CrossRef]

118. Kerle, E.A.; Jenkins, J.J.; Vogue, P.A. Understanding Pesticide Persistence and Mobility for Groundwater and Surface Water Protection; Extension \& Station Communications Oregon State University: Corvallis, OR, USA, 2007.

119. Reichenberger, S.; Bach, M.; Skitschak, A.; Frede, H.G. Mitigation strategies to reduce pesticide inputs into ground-and surface water and their effectiveness, A review. Sci. Total Environ. 2007, 384, 1-35. [CrossRef]

120. Marín-Benito, J.M.; Rodríguez-Cruz, M.S.; Sánchez-Martín, M.J. Effect of spent mushroom substrate amendment of vineyard oils on the behavior of fungicides: 2. Mobility of penconazole and metalaxyl in undisturbed soil cores. J. Agric. Food Chem. 2009, 57, 9643-9650. [CrossRef] [PubMed]

121. Marín-Benito, J.M.; Rodríguez-Cruz, M.S.; Sánchez-Martín, M.J.; Mamy, L. Modeling fungicides mobility in undisturbed vineyard soil cores unamended and amended with spent mushroom substrates. Chemosphere 2015, 134, 408-416. [CrossRef]

122. López-Piñeiro, J.A.; Peña, D.; Albarrán, A.; Sánchez-Llerena, J.; Becerra, D. Behavior of MCPA in four intensive cropping soils amended with fresh, composted, and aged olive mill waste. J. Contam. Hydrol. 2013, 152, 137-146. [CrossRef] [PubMed]

123. Aharonov-Nadborny, R.; Raviv, M.; Graber, E.R. Soil spreading of liquid olive mill processing wastes impacts leaching of adsorbed terbuthylazine. Chemosphere 2016, 156, 220-227. [CrossRef] [PubMed]

124. Fenoll, J.; Vela, N.; Navarro, G.; Perez-Lucas, G.; Navarro, S. Assessment of agro-industrial and composted organic wastes for reducing the potential leaching of triazine herbicide residues through the soil. Sci. Total Environ. 2014, 493, 124132. [CrossRef]

125. Larsbo, M.; Löfstrand, E.; de Veer, D.V.; Ulén, B. Pesticide leaching from two Swedish top soils of contrasting texture amended with biochar. J. Contam. Hydrol. 2013, 147, 73-81. [CrossRef]

126. Gámiz, B.; Velarde, P.; Spokas, K.A.; Hermosín, M.C.; Cox, L. Biochar soil additions affect herbicide fate: Importance of application timing and feedstock species. J. Agric. Food Chem. 2017, 65, 3109-3117. [CrossRef]

127. Gámiz, B.; Cox, L.; Hermosín, M.C.; Spokas, K.; Celis, R. Assessing the effect of organoclays and biochar on the fate of abscisic acid in soil. J. Agric. Food Chem. 2017, 65, 29-38. [CrossRef] 
128. Majumdar, K.; Singh, N. Effect of soil amendments on sorption and mobility of metribuzin in soils. Chemosphere 2007, 66, 630-637. [CrossRef]

129. Ghosh, R.K.; Singh, N. Managing metolachlor and atrazine leaching losses using lignite fly ash. Ecotoxicol. Environ. Saf. 2012, 84, 243-248. [CrossRef] [PubMed]

130. Fernández-Bayo, J.D.; Nogales, R.; Romero, E. Winery vermicomposts to control the leaching of diuron, imidacloprid and their metabolites: Role of dissolved organic carbon content. J. Environ. Sci. Health B 2015, 50, 190-200. [CrossRef]

131. Fenoll, J.; Garrido, I.; Hellin, P.; Flores, P.; Vela, N.; Navarro, S. Use of different organic wastes as strategy to mitigate the leaching potential of phenylurea herbicides through the soil. Environ. Sci. Pollut. Res. 2015, 22, 4336-4349. [CrossRef]

132. Barba, V.; Marín-Benito, J.M.; Sánchez-Martín, M.J.; Rodríguez-Cruz, M.S. Transport of ${ }^{14}$ C-prosulfocarb through soil columns under different amendment, herbicide incubation and irrigation regimes. Sci. Total Environ. 2020, 701, 1-8. [CrossRef]

133. Delwiche, K.B.; Lehmann, J.; Walter, M.T. Atrazine leaching from biochar-amended soils. Chemosphere 2014, 95, 346-352. [CrossRef]

134. Yu, X.Y.; Ying, G.G.; Kookana, R.S. Sorption and desorption behaviors of diuron in soils amended with charcoal. J. Agric. Food. Chem. 2006, 54, 8545-8550. [CrossRef] [PubMed]

135. Tang, Z.; Huang, Q.; Yang, Y.; Zhu, X.; Fu, H. Organochlorine pesticides in the lower reaches of Yangtze River: Occurrence, ecological risk and temporal trends. Ecotoxicol. Environ. Saf. 2013, 87, 89-97. [CrossRef] [PubMed]

136. Wang, J.; Zhang, M.; Xiong, Z.; Liu, P.; Pan, G. Effects of biochar addition on $\mathrm{N}_{2} \mathrm{O}$ and $\mathrm{CO}_{2}$ emissions from two paddy soils. Biol. Fertil. Soils. 2011, 47, 887-896. [CrossRef]

137. Pérez-Lucas, G.; Vela, N.; Escudero, J.A.; Navarro, G.; Navarro, S. Valorization of organic wastes to reduce the movement of priority substances through a semiarid soil. Water Air Soil Pollut 2017, 228, 119. [CrossRef]

138. Samarendra-Singh, N.; Irani, S.; Shaon, M.; Das, K. Leaching of Clothianidin in Two Different Indian Soils: Effect of Organic Amendment. Bull. Environ. Contam. Toxicol. 2018, 100, 553-559. [CrossRef] [PubMed]

139. Cederlund, H.; Börjesson, E.; Stenström, J. Effects of a wood-based biochar on the leaching of pesticides chlorpyrifos, diuron, glyphosate and MCPA. J. Environ. Manag. 2017, 191, 28-34. [CrossRef]

140. Ling, W.; Xu, J.; Gao, Y. Dissolved organic matter enhances the sorption of atrazine by soils. Biol. Fertil. Soils 2006, 42, 418-425. [CrossRef]

141. Chabauty, F.; Pot, V.; Bourdat-Deschamps, M.; Bernet, N.; Labat, C.; Benoit, P. Transport of organic contaminants in subsoil horizons and effects of dissolved organic matter related to organic waste recycling practices. Environ. Sci. Pollut. Res. Int. 2016, 23, 6907-6918. [CrossRef]

142. Huang, Y.; Xiao, L.; Li, F.; Xiao, M.; Lin, D.; Long, X.; Wu, Z. Microbial degradation of pesticide residues and an emphasis on the degradation of cypermethrin and 3-phenoxy benzoic acid: A review. Molecules 2018, 23, 2313. [CrossRef]

143. Alexander, M. How toxic are toxic chemicals in soil. Environ. Sci. Technol. 1995, 29, 2713-2717. [CrossRef] [PubMed]

144. Kulshrestha, G.; Singh, S.B.; Lal, S.P.; Yaduraju, N.T. Effect of long-term field application of pendimethalin: Enhanced degradation in soil. Pest Manag. Sci. 2000, 56, 202-206. [CrossRef]

145. Luo, Y.; Atashgahi, S.; Rijnaarts, H.H.M.; Comans, R.N.J.; Sutton, N.B. Influence of different redox conditions and dissolved organic matter on pesticide biodegradation in simulated groundwater systems. Sci. Total Environ. 2019, 677, 692-699. [CrossRef]

146. Yavari, S.; Sapari, N.B.; Malakahmad, A.; Yavari, S. Degradation of imazapic and imazapyr herbicides in the presence of optimized oil palm empty fruit bunch and rice husk biochars in soil. J. Hazard. Mater. 2019, 366, 636-642. [CrossRef] [PubMed]

147. Sánchez, M.E.; Estrada, I.B.; Martínez, O.; Martín-Villacorta, J.; Aller, A.; Morán, A. Influence of the application of sewage sludge on the degradation of pesticides in the soil. Chemosphere 2004, 57,673-679. [CrossRef]

148. Arias-Estévez, M.; López-Periago, E.; Martínez-Carballo, E.; Simal-Gándara, J.; Mejuto, J.C.; García-Río, L. The mobility and degradation of pesticides in soils and the pollution of groundwater resources. Agric. Ecosyst. Environ. 2008, 123, 247-260. [CrossRef]

149. Herrero-Hernández, E.; Marín-Benito, J.M.; Andrades, M.S.; Sánchez-Martín, M.J.; Rodríguez-Cruz, M.S. Field versus laboratory experiments to evaluate the fate of azoxystrobin in an amended vineyard soil. J. Environ Manag. 2015, 163, 78-86. [CrossRef] [PubMed]

150. Hussain, S.; Arshad, M.; Springael, D.; SøRensen, S.R.; Bending, G.D.; Devers-Lamrani, M.; Maqbool, Z.; Martin-Laurent, F. Abiotic and biotic processes governing the fate of phenylurea herbicides in soils: A review. Crit. Rev. Environ. Sci. Technol. 2015, 45, 1947-1998. [CrossRef]

151. Álvarez-Martín, A.; Sánchez-Martín, M.J.; Pose-Juan, E.; Rodríguez-Cruz, M.S. Effect of different rates of spent mushroom substrate on the dissipation and bioavailability of cymoxanil and tebuconazole in an agricultural soil. Sci. Total Environ. 2016, 550, 495-503. [CrossRef]

152. Flores-Céspedes, F.; Fernández-Pérez, M.; Villafranca-Sánchez, M.; González-Pradas, E. Co-sorption study of organic pollutants and dissolved organic matter in a soil. Environ. Pollut. 2006, 142, 449-456. [CrossRef] [PubMed]

153. Rodríguez-Liébana, J.A.; ElGouzi, S.; Peña, A. Laboratory persistence in soil of thiacloprid, pendimethalin and fenarimol incubated with treated wastewater and dissolved organic matter solutions. Contribution of soil biota. Chemosphere 2017, 181, 508-517. [CrossRef]

154. Karanasios, E.; Tsiropoulos, N.G.; Karpouzas, D.G.; Ehaliotis, C. Degradation and adsorption of pesticides in compost-based biomixtures as potential substrates for biobeds in southern Europe. J. Agric. Food Chem. 2010, 58, 9147-9156. [CrossRef] 
155. Karanasios, E.; Tsiropoulos, N.G.; Karpouzas, D.G.; Menkissoglu-Spiroudi, U. Novel biomixtures based on local Mediterranean lignocellulosic materials: Evaluation for use in biobed systems. Chemosphere 2010, 80, 914-921. [CrossRef] [PubMed]

156. García-Delgado, C.; D'Annibale, A.; Pesciaroli, L.; Yunta, F.; Crognale, S.; Petruccioli, M.; Eymar, E. Implications of polluted soil biostimulation and bioaugmentation with spent mushroom substrate (Agaricus bisporus) on the microbial community and polycyclic aromatic hydrocarbons biodegradation. Sci. Total Environ. 2015, 508, 20-28. [CrossRef]

157. Castillo, M.P.; Torstensson, L. Effect of biobed composition, moisture and temperature on the degradation of pesticides. J. Agric. Food Chem. 2007, 55, 5725-5733. [CrossRef]

158. Tang, F.; Xu, Z.; Gao, M.; Li, L.; Li, H.; Cheng, H.; Tian, G. The dissipation of cyazofamid and its main metabolite in soil response oppositely to biochar application. Chemosphere 2019, 218, 26-35. [CrossRef] [PubMed]

159. Su, W.; Hao, H.; Ding, M.; Wu, R.; Xu, H.; Xue, F.; Lu, C. Adsorption and degradation of imazapic in soils under different environmental conditions. PLoS ONE 2019, 14, e0219462. [CrossRef] [PubMed]

160. Marín-Benito, J.M.; Carpio, M.J.; Sánchez-Martín, M.J.; Rodríguez-Cruz, M.S. Previous degradation study of two herbicides to simulate their fate in a sandy loam soil: Effect of the temperature and the organic amendments. Sci. Total Environ. 2019, 653, 1301-1310. [CrossRef]

161. Barba, V.; Marín-Benito, J.M.; García-Delgado, C.; Sánchez-Martín, M.J.; Rodríguez-Cruz, M.S. Assessment of ${ }^{14}$ C-prosulfocarb dissipation mechanism in soil after amendment and its impact on the microbial community. Ecotoxicol. Environ. Saf. 2019, 182, 109395. [CrossRef] [PubMed]

162. Fang, H.; Lian, J.; Wang, H.; Cai, L.; Yu, Y. Exploring bacterial community structure and function associated with atrazine biodegradation in repeatedly treated soils. J. Hazard. Mater. 2015, 286, 457-465. [CrossRef]

163. Wang, F.; Zhu, L.; Wang, X.; Wang, J.; Wang, J. Impact of repeated applications of metalaxyl on its dissipation and microbial community in soil. Water Air Soil Pollut. 2015, 226, 1-14. [CrossRef]

164. Xu, J.; Zhang, Y.; Dong, F.; Liu, X.; Wu, X.; Zheng, Y. Effects of repeated applications of chlorimuron-ethyl on the soil microbial biomass, activity and microbial community in the greenhouse. Bull. Environ. Contam. Toxicol. 2014, 92, 175-182. [CrossRef]

165. Pose-Juan, E.; Igual, J.M.; Sánchez-Martín, M.J.; Rodríguez-Cruz, M.S. Influence of herbicide triasulfuron on soil microbial community in an unamended soil and a soil amended with organic residues. Front. Microbiol. 2017, 8, 1-12. [CrossRef]

166. Singh, S.; Kumar, V.; Chauhan, A.; Datta, S.; Wani, A.B.; Singh, N.; Singh, J. Toxicity, degradation and analysis of the herbicide atrazine. Environ. Chem. Lett. 2018, 16, 211-237. [CrossRef]

167. Pose-Juan, E.; Marín-Benito, J.M.; Sánchez-Martín, M.J.; Rodríguez-Cruz, M.S. Dissipation of herbicides after repeated application in soils amended with green compost and sewage sludge. J. Environ. Manag. 2018, 223, 1068-1077. [CrossRef]

168. Marín-Benito, J.M.; Barba, V.; Ordax, J.M.; Andrades, M.S.; Sánchez-Martín, M.J.; Rodríguez-Cruz, M.S. Application of green compost as amendment in an agricultural soil: Effect on the behaviour of triasulfuron and prosulfocarb under field conditions. $J$. Environ. Manag. 2018, 207, 180-191. [CrossRef] [PubMed]

169. Marín-Benito, J.M.; Barba, V.; Ordax, J.M.; Sánchez-Martín, M.J.; Rodríguez-Cruz, M.S. Recycling organic residues in soils as amendments: Effect on the mobility of two herbicides under different management practices. J. Environ. Manag. 2018, 224, 172-181. [CrossRef] [PubMed]

170. Carpio, M.J.; Rodríguez-Cruz, M.S.; García-Delgado, C.; Sánchez-Martín, M.J.; Marín-Benito, J.M. Mobility monitoring of two herbicides in amended soils: A field study for modeling applications. J. Environ. Manag. 2020, 260, 110161. [CrossRef]

171. FOCUS (Forum for Coordination of Pesticide Fate Models and Their Use). FOCUS Groundwater Scenarios in the EU Review of Active Substances; Report of the FOCUS Groundwater Scenarios Workgroup EC; Document Reference Sanco/321/2000 Rev.2; European Commission: Luxembourg, 2000; p. 202.

172. Marín-Benito, J.M.; Mamy, L.; Carpio, M.J.; Sánchez-Martín, M.J.; Rodríguez-Cruz, M.S. Sci. Total Environ. Modelling herbicides mobility in amended soils: Calibration and test of PRZM and MACRO. Sci. Total Environ. 2020, 717, 137019. [CrossRef]

173. Marín-Benito, J.M.; Carpio, M.J.; Mamy, L.; Andrades, M.S.; Sánchez-Martín, M.J.; Rodríguez-Cruz, M.S. Field measurement and modelling of chlorotoluron and flufenacet persistence in unamended and amended soils. Sci. Total Environ. 2020, 725, 138374. [CrossRef] [PubMed] 